\title{
Comparison of clinical practice guidelines for the management of chronic hepatitis B: When to start, when to change, and when to stop
}

\author{
Hyung Joon Yim 1 , Ji Hoon Kim', Jun Yong Park², Eileen L. Yoon ${ }^{3}$, Hana Park ${ }^{4}$, Jung Hyun Kwon ${ }^{5}$, Dong Hyun Sinn ${ }^{6}$, \\ Sae Hwan Lee, Jeong-Hoon Lee ${ }^{8}$, and Hyun Woong Lee ${ }^{2}$

\begin{abstract}
'Department of Internal Medicine, Korea University College of Medicine, Seoul; '2Department of Internal Medicine, Yonsei University College of Medicine, Seoul; ${ }^{3}$ Department of Internal Medicine, Inje University College of Medicine, Seoul; ${ }^{4}$ Department of Health Medicine, Asan Medical Center, Seoul; ${ }^{5}$ Department of Internal Medicine, College of Medicine, the Catholic University of Korea, Seoul; ${ }^{6}$ Department of Internal Medicine, Sungkyunkwan University School of Medicine, Seoul; ${ }^{7}$ Department of Internal Medicine, Soonchunhyang University College of Medicine, Chonan; ${ }^{8}$ Department of Internal Medicine, Seoul National University College of Medicine, Seoul,
\end{abstract} \\ Korea
}

Clinical practice guidelines are important for guiding the management of specific diseases by medical practitioners, trainees, and nurses. In some cases, the guidelines are utilized as a reference for health policymakers in controlling diseases with a large public impact. With this in mind, practice guidelines for the management of chronic hepatitis B (CHB) have been developed in the United States, Europe, and Asian-Pacific regions to suggest the best-fit recommendations for each social and medical circumstance. Recently, the Korean Association for the Study of the Liver published a revised version of its clinical practice guidelines for the management of CHB. The guidelines included updated information based on newly available antiviral agents, the most recent opinion on the initiation and cessation of treatment, and updates for the management of drug resistance, partial virological response, and side effects. Additionally, CHB management in specific situations was comprehensively revised. This review compares the similarities and differences among the various practice guidelines to identify unmet needs and improve future recommendations. (Clin Mol Hepatol 2020;26:411-429)

Keywords: Hepatitis B, Chronic; Hepatitis B virus; Clinical practice guidelines

\section{INTRODUCTION}

Chronic hepatitis B virus (HBV) infection is a global health problem. ${ }^{1}$ Although several therapeutic agents have been approved and used for patients with HBV infection, the disease remains difficult to cure, and the eradication of chronic infections remains challenging. ${ }^{2-5}$ Current clinical practice guidelines or guidance by the American Association for the Study of Liver Diseases (AAS-

\footnotetext{
Abbreviations:

AASLD, American Association for the Study of Liver Diseases; ALT, alanine aminotransferase; APASL, Asian-Pacific Association for the Study of the Liver; CHB, chronic hepatitis B; EASL, European Association for the Study of the Liver; $\mathrm{HBeAg}$, hepatitis B virus e antigen; HBsAg, hepatitis B virus surface antigen; $\mathrm{HBV}$, hepatitis B virus; HCC, hepatocellular carcinoma; KASL, Korean Association for the Study of the Liver; NA, nucleos(t)ide analog; PVR, partial virological responses; tenofovir $A F$, tenofovir alafenamide; tenofovir $D F$, tenofovir disoproxi fumarate; ULN, upper limit of the normal
}

Corresponding author: Hyung Joon Yim

Department of Internal Medicine, Korea University Ansan Hospital, 123 Jeokgeum-ro, Danwon-gu, Ansan 15355, Korea

Tel: +82-31-412-6565, Fax: +82-31-412-5582

E-mail: gudwns21@korea.ac.kr

https://orcid.org/0000-0002-6036-2754 
LD), ${ }^{6}$ European Association for the Study of the Liver (EASL), and Asian-Pacific Association for the Study of the Liver (APASL) provides general recommendations for the management of chronic hepatitis B (CHB) (Table 1). ${ }^{8}$ Recently, in 2019, the Korean Association for the Study of the Liver (KASL) published new clinical practice guidelines for the management of CHB in this journal and described comprehensive management strategies including prevention, monitoring, treatment, and special considerations. ${ }^{9}$ Here, we compare the Korean guidelines with other international guidelines regarding when to start, when to change, and when to stop antiviral treatment for CHB.

\section{NATURAL HISTORY}

CHB is a life-long disease that can start at the beginning of life by perinatal transmission, especially in Asian countries. ${ }^{3}$ Five characteristic phases of CHB have been identified according to immunological features, virology, biochemistry, and histology (Table 2). ${ }^{3}$

The first phase is the CHB immune tolerant phase (immune tolerant CHB). It is characterized by very high levels of HBV replication, persistently normal alanine aminotransferase (ALT) levels, and minimal or no necroinflammatory activity. During this phase, patients are typically positive and show high titers of hepatitis B surface antigen (HBsAg) and hepatitis B e antigen (HBeAg). Inflammatory activity is assumed to be absent, which prompted the EASL to revise the name of the first phase to $\mathrm{HBeAg}$-positive chronic HBV infection. ' However, normal ALT levels do not exclude the presence of necroinflammation and fibrosis, particularly as determined by conventional laboratory criteria. ${ }^{10,11}$ Therefore, the KASL adjusted the cut-off of normal ALT to $34 \mathrm{IU} / \mathrm{L}$ for males and $30 \mathrm{IU} / \mathrm{mL}$ for females on the basis of a recent study involving 12,486 Korean CHB patients. ${ }^{9,12}$ Experts from the AASLD recommended the use of similar cut-offs of $35 \mathrm{IU} / \mathrm{L}$ for males and $25 \mathrm{IU} / \mathrm{mL}$ for females, whereas the EASL and APASL insist on using traditional laboratory reference values of $40 \mathrm{IU} / \mathrm{mL}$ for both sexes (Table 1). ${ }^{6}$ Another issue differentiating the immune tolerant phase from other phases is the cut-off of the very high HBV DNA levels. The HBV DNA criterion ( $\geq 10^{7} \mathrm{IU} / \mathrm{mL}$ ) for the immune tolerant phase as defined by the KASL and EASL is somewhat different from that of the AASLD $\left(>10^{6} \mathrm{IU} / \mathrm{mL}\right)$ and the APASL $\left(>2 \times 10^{6}\right.$ $\mathrm{IU} / \mathrm{mL})^{6.9}$ However, given that a decreasing HBV DNA titer suggests immunological interactions between the host and virus, a higher cut-off would be suitable to exclude patients in transition phases who may need antiviral treatment. ${ }^{13}$ Indeed, the definition of the immune tolerant phase is still under debate, ${ }^{13,14}$ causing investigators to continue evaluating the appropriate cut-offs of the ALT and HBV DNA levels for the accurate prediction of long-term

Table 1. Comparison of current clinical practice guidelines for chronic hepatitis B management

\begin{tabular}{|c|c|c|c|c|}
\hline & KASL & AASLD & EASL & APASL \\
\hline Published year & June 2019 & April 2018 & August 2017 & January 2016 \\
\hline Journal & $\begin{array}{l}\text { Clinical Molecular } \\
\text { Hepatology }\end{array}$ & Hepatology & Journal of Hepatology & $\begin{array}{l}\text { Hepatology } \\
\text { International }\end{array}$ \\
\hline Type & $\begin{array}{l}\text { Clinical practice } \\
\text { guidelines }\end{array}$ & $\begin{array}{l}\text { Guidance incorporated with } \\
\text { guidelines }\end{array}$ & $\begin{array}{l}\text { Clinical practice } \\
\text { guidelines }\end{array}$ & $\begin{array}{l}\text { Clinical practice } \\
\text { guidelines }\end{array}$ \\
\hline Listed author(s) & KASL & $\begin{array}{l}\text { An expert panel of the } \\
\text { AASLD }\end{array}$ & EASL & $\begin{array}{c}\text { A panel of Asian experts } \\
\text { chosen by the APASL }\end{array}$ \\
\hline Recommendation & GRADE & $\begin{array}{l}\text { Guidance developed by the } \\
\text { consensus of an expert } \\
\text { panel, GRADE (2016) }\end{array}$ & GRADE & GRADE \\
\hline Interval since the previous update & 3 years & 2 years & 5 years & 4 years \\
\hline Target population & Korean & American & European & Asian \\
\hline \multicolumn{5}{|l|}{ Suggested normal ALT (IU/L) } \\
\hline Male & $<34$ & $<35$ & $<40$ & $<40$ \\
\hline Female & $<30$ & $<25$ & $<40$ & $<40$ \\
\hline
\end{tabular}

KASL, Korean Association for the Study of the Liver; AASLD, American Association for the Study of Liver Diseases; EASL, European Association for the Study of the Liver; APASL, Asian-Pacific Association for the Study of the Liver; GRADE, Grading of Recommendations Assessment, Development and Evaluation system; ALT, alanine aminotransferase. 
prognosis and recommendation of suitable treatment.

The second phase is the HBeAg-positive immune active phase. This is also termed the immune reactive or immune clearance phase. ${ }^{3}$ The level of HBV DNA remains high $\left(10^{4}-10^{7} \mathrm{IU} / \mathrm{mL}\right.$ according to the EASL) but may fluctuate. ${ }^{3}$ Elevated ALT suggests the presence of intrahepatic necroinflammation and can be associated with liver damage. ${ }^{15}$ The outcome of this phase varies according to the degree of liver injury; thus, prompt antiviral therapy is recommended. 15

The third phase is the immune inactive phase, previously known as the immune controlled phase. ${ }^{3}$ Other terminologies for this phase include HBeAg-negative chronic HBV infection, as proposed by the EASL, and low replicative chronic HBV infection or low replicative phase, as proposed by the APASL, ${ }^{7,8}$ emphasizing the mini- mal intrahepatic inflammation and low viral replication. The level of HBV DNA is typically as low as $<2,000 \mathrm{IU} / \mathrm{mL}$, and the ALT level is within the upper limit of the normal (ULN) range. If patients remain in this phase, prognosis is favorable, and the HBsAg levels may decrease at $1-3 \%$ per year. However, low level persistent viremia can be associated with live disease progression, and a number of patients transit to the HBeAg-negative immune-active phase of CHB annually. ${ }^{16}$

The fourth phase is the HBeAg-negative CHB immune active phase, which was previously known as the immune escape phase or reactivation phase. ${ }^{3,17}$ The moderate to high levels of HBV replication $(>2,000 \mathrm{IU} / \mathrm{mL})$ and negative $\mathrm{HBeAg}$ status in this phase are caused by mutations on the pre-core or core promoter regions of HBV DNA, blocking HBeAg production. ${ }^{18,19}$ The prolonged viral

Table 2. Comparison of terminology and characteristics associated with the natural history of chronic hepatitis B

\begin{tabular}{|c|c|c|c|c|c|}
\hline & Phase 1 & Phase 2 & Phase 3 & Phase 4 & Phase 5 \\
\hline \multicolumn{6}{|l|}{ Terminology } \\
\hline KASL & $\begin{array}{l}\text { Immune tolerant CHB } \\
\text { (CHB, immune } \\
\text { tolerant phase) }\end{array}$ & $\begin{array}{l}\text { Immune active } \\
\text { HBeAg-positive CHB } \\
\text { (HBeAg-positive } \\
\text { CHB, immune active } \\
\text { phase) }\end{array}$ & $\begin{array}{l}\text { Immune inactive CHB } \\
\text { (CHB, Immune } \\
\text { inactive phase) }\end{array}$ & $\begin{array}{l}\text { Immune active } \mathrm{HBeAg} \text { - } \\
\text { negative } \mathrm{CHB} \\
\text { (HBeAg-negative } \\
\text { CHB, immune active } \\
\text { phase) }\end{array}$ & $\begin{array}{l}\text { Resolved CHB, } \\
\text { (HBsAg loss } \\
\text { phase) }\end{array}$ \\
\hline AASLD & Immune tolerant $\mathrm{CHB}$ & $\begin{array}{l}\text { Immune active } \mathrm{HBeAg} \text { - } \\
\text { positive } \mathrm{CHB}\end{array}$ & Inactive CHB & $\begin{array}{l}\text { Immune active } \mathrm{HBeAg} \text { - } \\
\text { negative } \mathrm{CHB}\end{array}$ & $\begin{array}{l}\text { Resolved CHB } \\
\text { (functional cure } \\
\text { state) }\end{array}$ \\
\hline EASL & $\begin{array}{l}\text { HBeAg-positive } \\
\text { chronic HBV infection }\end{array}$ & HBeAg-positive CHB & $\begin{array}{l}\text { HBeAg-negative } \\
\text { chronic HBV infection }\end{array}$ & HBeAg-negative CHB & $\begin{array}{l}\text { Resolved HBV } \\
\text { infection }\end{array}$ \\
\hline APASL & $\begin{array}{l}\text { Immune tolerant } \\
\text { chronic HBV infection } \\
\text { (immune tolerant } \\
\text { phase) }\end{array}$ & $\begin{array}{l}\text { HBeAg-positive CHB } \\
\text { (immune reactive } \\
\text { phase) }\end{array}$ & $\begin{array}{l}\text { Low replicative chronic } \\
\text { HBV infection (low } \\
\text { replicative phase) }\end{array}$ & $\begin{array}{l}\text { HBeAg-negative CHB } \\
\text { (reactivation phase) }\end{array}$ & $\begin{array}{l}\text { Resolved hepatitis } \\
\text { B infection }\end{array}$ \\
\hline \multicolumn{6}{|l|}{ Characteristics } \\
\hline $\mathrm{HBsAg}$ & High & High/intermediate & Low & Intermediate & Negative \\
\hline $\mathrm{HBeAg}$ & Positive & Positive & Negative & Negative & Negative \\
\hline HBV DNA level & $>10^{6}-10^{7 *} \mathrm{IU} / \mathrm{mL}$ & $\begin{array}{l}>2 \times 10^{4} \mathrm{IU} / \mathrm{mL} \\
\left(10^{4}-10^{7} \mathrm{IU} / \mathrm{mL}\right)^{\ddagger}\end{array}$ & $<2,000 \mathrm{IU} / \mathrm{mL}$ & $>2,000 \mathrm{IU} / \mathrm{mL}$ & Undetectable \\
\hline ALT level & Persistently normal & Elevated & Persistently normal & Elevated & Normal \\
\hline Histological activity $^{\dagger}$ & None/minimal & Moderate/severe & Minimal & Moderate/severe & None \\
\hline
\end{tabular}

KASL, Korean Association for the Study of the Liver; CHB, chronic hepatitis B; HBeAg, hepatitis B e antigen; HBsAg, hepatitis B surface antigen; AASLD, American Association for the Study of Liver Diseases; EASL, European Association for the Study of the Liver; APASL, Asian-Pacific Association for the Study of the Liver; HBV, hepatitis B virus; ALT, alanine aminotransferase.

${ }^{*} \mathrm{HBV}$ DNA $>10^{6} \mathrm{IU} / \mathrm{mL}$ by the AASLD, HBV DNA $>10^{7} \mathrm{IU} / \mathrm{mL}$ by the KASL and EASL, and no clear cut-off by the APASL although ranges from $>2 \times 10^{6}-10^{7} \mathrm{IU} / \mathrm{mL}$ are favored.

${ }^{\dagger}$ Activity depends on necroinflammation, and fibrosis stage can vary according to the degree of liver injury accumulation.

${ }^{\ddagger}$ EASL criteria for HBeAg-positive chronic hepatitis B. 


\section{CLINCAL and MOLECULAR
HEPATOLOGY}

replication and intrahepatic necroinflammation observed during this phase are associated with progression to liver cirrhosis or the development of hepatocellular carcinoma (HCC), ${ }^{3,20}$

The last phase is the HBsAg loss phase, in which HBsAg is spontaneously cleared. ${ }^{21}$ Although the incidence of HBsAg loss is very low $(<0.5 \%$ per year), the risk of disease progression substantially decreases. ${ }^{21,22}$ However, HCC surveillance should be continued if HBsAg loss occurs after age $\geq 50$ years as recommended by the KASL. The AASLD suggests continued HCC surveillance in patients with $\mathrm{HBsAg}$ loss after ages $>40$ years for males and $>50$ years for females. ${ }^{6,9}$

\section{TREATMENT GOALS AND AIMS}

The treatment goals and aims were updated in the KASL guidelines. ${ }^{9}$ The goals of treatment are to decrease mortality due to liver disease and improve survival by preventing the progression of liver fibrosis to cirrhosis and preventing HCC, which are consistent with other guidelines. ${ }^{7.8}$ The aims of anti-HBV treatment suggested by the KASL include ALT normalization, undetectable serum HBV DNA, serum HBeAg loss or seroconversion, and serum HBsAg loss or seroconversion. ${ }^{9}$ Specifically, serum HBsAg loss or seroconversion is proposed as an ideal endpoint for $\mathrm{CHB}$ treatment. ${ }^{9}$ The EASL also suggests HBsAg loss with or without anti-HBs se- roconversion as an optimal endpoint, whereas the APASL considers HBsAg loss an ideal, although not realistic, endpoint. ${ }^{7.8}$ Hence, the APASL suggests a sustained off-therapy virological response in both HBeAg-positive (with HBeAg to anti-HBe seroconversion) and HBeAg-negative patients as a satisfactory endpoint. ${ }^{8}$

\section{WHEN TO START: COMPARISON OF TREAT- MENT INDICATORS}

High level HBV replication is associated with an increased risk of liver damage and liver-related complications. ${ }^{23,24}$ Antiviral therapy using interferons or nucleos(t)ide analogs (NAs) efficiently reduces these risks by suppressing HBV replication. ${ }^{25-29}$ Current guidelines recommend treatment initiation with antiviral agents before the accumulation of liver injury or progression of fibrosis. However, intrahepatic covalently closed circular DNA cannot be eradicated, even with long-term treatment. ${ }^{6-9}$ To determine when to initiate antiviral treatment, the level of HBV replication by HBV DNA measurement, the degree of liver injury measured by ALT or liver biopsy, and the stage of liver fibrosis assessed by noninvasive methods or liver biopsy should be considered (Fig. 1). ${ }^{9,30}$ Additionally, information regarding age, co-morbidity, and family history of HCC or liver cirrhosis may be helpful in determining when to start treatment.
HBeAg-positive status without cirrhosis

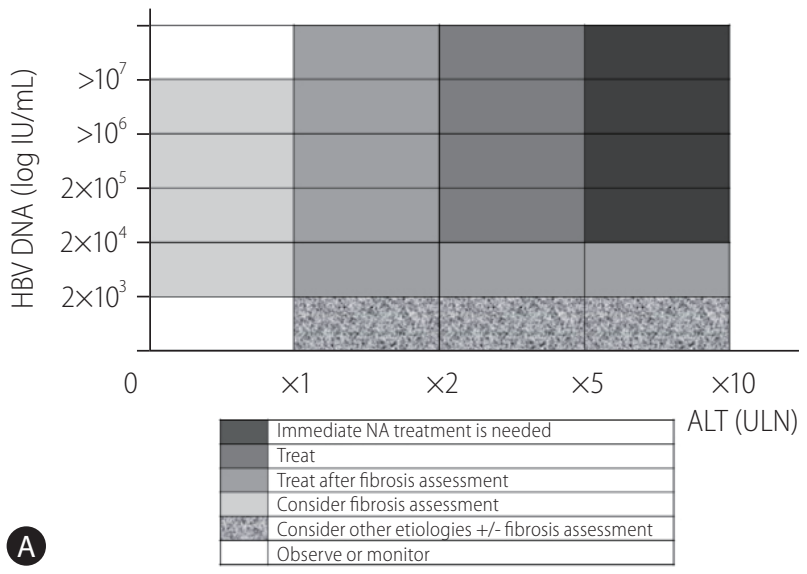

HBeAg-nagative status without cirrhosis

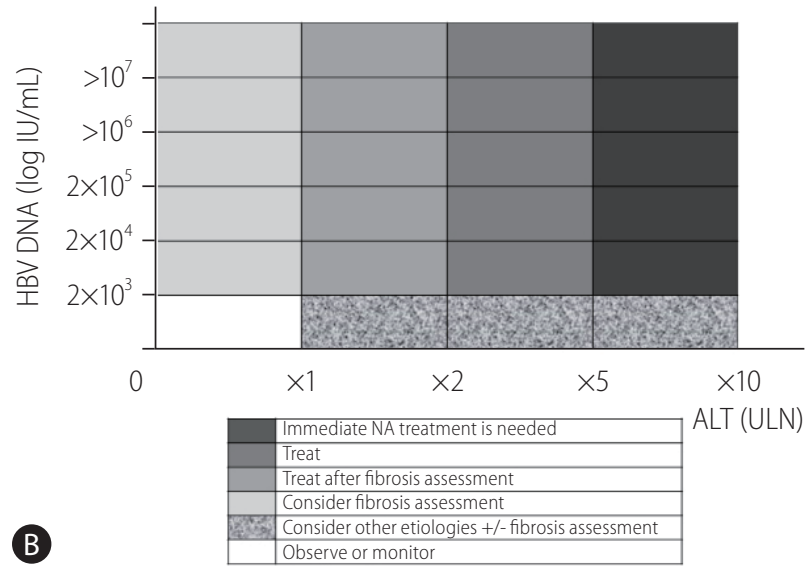

Figure 1. Nomogram of treatment indicators for chronic hepatitis B without liver cirrhosis for (A) HBeAg-positive patients and (B) HBeAg-negative patients. Gradation toward dark gray suggests immediate treatment, and gradation toward white suggests observation and monitoring. Intermediate gradation suggests the need for fibrosis assessment before determining treatment according to the international guidelines and the Korean Association for the Study of Liver Guidelines. The initiation of antiviral therapy is indicated by a noninvasive fibrosis test suggesting evidence of significant fibrosis or a liver biopsy showing significant necroinflammation or fibrosis ( $\geq A 2$ or $\geq F 2$ ). HBeAg, hepatitis $B$ e antigen; HBV, hepatitis B virus; ALT, alanine aminotransferase; ULN, upper limit of normal; NA, nucleos(t)ide analog. 
Table 3. Comparison of treatment indicators for chronic hepatitis B

\begin{tabular}{|c|c|c|c|c|}
\hline & KASL & AASLD & EASL & APASL \\
\hline \multirow[t]{2}{*}{$\begin{array}{l}\text { Immune } \\
\text { tolerant } \\
\text { CHB } \\
\text { 1) Monitor } \\
\text { 2) Consider }\end{array}$} & $\begin{array}{l}\text { 1) Monitor patients with very } \\
\text { high HBV DNA }\left(\geq 10^{7} \mathrm{IU} / \mathrm{mL}\right) \\
\text { and normal ALT (male }<34 \\
\text { IU/mL, female }<30 \mathrm{IU} / \mathrm{mL})\end{array}$ & $\begin{array}{l}\text { 1) Monitor patients with high } \\
\text { HBV DNA }\left(\geq 10^{6} \mathrm{IU} / \mathrm{mL} \text { ) and }\right. \\
\text { normal ALT (male }<35 \\
\text { IU/mL, female }<25 \mathrm{IU} / \mathrm{mL})\end{array}$ & $\begin{array}{l}\text { 1) Monitor patients with high } \\
\text { HBV DNA }\left(\geq 10^{7} \mathrm{IU} / \mathrm{mL}\right) \text { and } \\
\text { normal } A L T(<40 \mathrm{IU} / \mathrm{L}) \\
\text { if there are no signs of } \\
\text { chronic hepatitis }\end{array}$ & $\begin{array}{l}\text { 1) Monitor patients with high } \\
\text { HBV DNA (e.g., }>2 \times 10^{6}-10^{7} \\
\text { IU/mL) and normal ALT }(<40 \\
\text { IU/L) if age }<30 \text { years }\end{array}$ \\
\hline & $\begin{array}{l}\text { 2) Liver biopsy to determine } \\
\text { treatment if there are risk } \\
\text { factors (age } \geq 30-40 \text { years, } \\
\text { HBV DNA levels }<10^{7} \mathrm{IU} / \mathrm{mL} \text {, } \\
\text { noninvasive fibrosis tests } \\
\text { suggesting significant } \\
\text { hepatic fibrosis, or ALT is } \\
\text { approaching the ULN) }\end{array}$ & $\begin{array}{l}\text { 2) Antiviral therapy is } \\
\text { suggested in selected } \\
\text { patients (age }>40 \text { years } \\
\text { with normal ALT and } \\
\text { elevated HBV DNA } \\
{[1,000,000 \mathrm{IU} / \mathrm{mL}] \text {, liver }} \\
\text { biopsy showing significant } \\
\text { necroinflammation or } \\
\text { fibrosis) }\end{array}$ & $\begin{array}{l}\text { 2) Antiviral therapy may be } \\
\text { indicated for patients }>30 \\
\text { years of age, regardless } \\
\text { of the severity of liver } \\
\text { histological lesions } \\
\text { Patients with a family history } \\
\text { of HCC or cirrhosis and } \\
\text { extrahepatic manifestations } \\
\text { can be treated }\end{array}$ & $\begin{array}{l}\text { 2) Liver biopsy if indicated } \\
\text { (age is }>35 \text { years or there } \\
\text { is a family history of HCC } \\
\text { or cirrhosis, noninvasive } \\
\text { tests suggest evidence } \\
\text { of significant fibrosis, } \\
\text { persistently elevated ALT) } \\
\text { Treat if } \geq \mathrm{A} 2 \text { or } \geq \mathrm{F} 2\end{array}$ \\
\hline \multirow[t]{2}{*}{$\begin{array}{l}\text { Immune } \\
\text { active CHB } \\
\text { 1) Treat } \\
\text { 2), 3) Consider }\end{array}$} & $\begin{array}{l}\text { 1) Treat if HBV DNA } \geq 20,000 \\
\text { (for HBeAg-positive CHB) or } \\
\geq 2,000 \text { (for HBeAg-negative } \\
\text { CHB) IU/mL and serum ALT } \\
\text { level } \geq 2 \times \text { ULN }\end{array}$ & $\begin{array}{l}\text { 1) Treat if elevated HBV DNA } \\
\text { ( } \geq 20,000 \mathrm{IU} / \mathrm{mL} \text { for HBeAg- } \\
\text { positive or } \geq 2,000 \mathrm{IU} / \mathrm{mL} \\
\text { for HBeAg-negative CHB) } \\
\text { and ALT } \geq 2 \times \text { ULN or there } \\
\text { is evidence of significant } \\
\text { histological disease }\end{array}$ & $\begin{array}{l}\text { 1) Treat if HBV DNA }>20,000 \\
I U / m L \text { and } A L T>2 \times U L N \text {, } \\
\text { regardless of the degree of } \\
\text { fibrosis }\end{array}$ & $\begin{array}{l}\text { 1) Treat if HBV DNA }>20,000 \\
\text { IU/mL for HBeAg-positive } \\
\text { or }>2,000 \text { IU/mL for HBeAg- } \\
\text { negative CHB and ALT levels } \\
\text { are elevated }>2 \times \text { ULN }\end{array}$ \\
\hline & $\begin{array}{l}\text { 2) Consider liver biopsy if ALT } \\
\text { is } 1-2 \times \text { ULN and treat if } \\
\text { there is moderate to severe } \\
\text { necroinflammation ( } \geq \mathrm{A} 2 \text { ) } \\
\text { or significant fibrosis ( } \geq \mathrm{F} 2) \\
\text { 3) In HBeAg-negative patients } \\
\text { with HBV DNA } \geq 2,000 \\
\text { IU/mL and normal ALT } \\
\text { levels, follow-up or liver } \\
\text { biopsy/noninvasive fibrosis } \\
\text { tests can be considered }\end{array}$ & $\begin{array}{l}\text { 2) Consider the severity of } \\
\text { liver disease to determine } \\
\text { treatment for patients with } \\
\text { ALT }>1-2 \times \text { ULN }\end{array}$ & $\begin{array}{l}\text { 2) Treat all patients with } \\
\text { HBeAg-positive or } \\
\text {-negative CHB, defined by } \\
\text { HBV DNA }>2,000 \mathrm{IU} / \mathrm{mL} \text {, } \\
\text { ALT>ULN }(40 \mathrm{IU} / \mathrm{L}) \text {, and/ } \\
\text { or at least moderate liver } \\
\text { necroinflammation or } \\
\text { fibrosis by biopsy }\end{array}$ & $\begin{array}{l}\text { 2) Patients with high HBV DNA } \\
\text { levels ( }>20,000 \mathrm{IU} / \mathrm{mL} \text { for } \\
\mathrm{HBeAg} \text {-positive and }>2,000 \\
\mathrm{IU} / \mathrm{mL} \text { for } \mathrm{HBeAg} \text {-negative } \\
\mathrm{CHB} \text { ) but ALT }<2 \times \text { ULN } \\
\text { should depict a noninvasive } \\
\text { fibrosis assessment } \\
\text { Biopsy should be considered if } \\
\text { indicated* } \\
\text { Antiviral therapy is } \\
\text { recommended if } \geq \mathrm{A} 2 \text { or } \geq F 2\end{array}$ \\
\hline \multirow{2}{*}{$\begin{array}{l}\text { Immune } \\
\text { inactive } \\
\text { CHB } \\
\text { 1) Monitor } \\
\text { 2) Consider }\end{array}$} & \multirow[t]{2}{*}{ 1) Monitor } & \multirow[t]{2}{*}{ 1) Monitor } & 1) Monitor & 1) Monitor \\
\hline & & & $\begin{array}{l}\text { 2) Patients with HBeAg- } \\
\text { negative chronic HBV } \\
\text { infection, family history } \\
\text { of HCC or cirrhosis, and } \\
\text { extrahepatic manifestations } \\
\text { can be treated even if } \\
\text { typical treatment } \\
\text { indications are not present }\end{array}$ & $\begin{array}{l}\text { 2) HBeAg-negative patients } \\
\text { with } \mathrm{HBV} \text { DNA }<2,000 \mathrm{IU} / \mathrm{mL} \text {, } \\
\text { should be evaluated for other } \\
\text { causes if ALT is elevated and } \\
\text { obtain a noninvasive fibrosis } \\
\text { assessment } \\
\text { Biopsy should be considered if } \\
\text { indicated* } \\
\text { Antiviral therapy is } \\
\text { recommended if } \geq \mathrm{A} 2 \text { or } \geq F 2\end{array}$ \\
\hline $\begin{array}{r}\text { First-line } \\
\text { agents }\end{array}$ & $\begin{array}{l}\text { Entecavir, tenofovir DF, } \\
\text { tenofovir AF, besifovir, } \\
\text { peg-interferon }\end{array}$ & $\begin{array}{l}\text { Entecavir, tenofovir DF, } \\
\text { tenofovir } A F, \\
\text { peg-interferon }\end{array}$ & $\begin{array}{l}\text { Entecavir, tenofovir DF, } \\
\text { tenofovir AF, peg-interferon }\end{array}$ & $\begin{array}{l}\text { Entecavir, tenofovir DF, } \\
\text { peg-interferon }\end{array}$ \\
\hline
\end{tabular}

KASL, Korean Association for the Study of the Liver; AASLD, American Association for the Study of Liver Diseases; EASL, European Association for the Study of the Liver; APASL, Asian-Pacific Association for the Study of the Liver; CHB, chronic hepatitis B; HBV, hepatitis B virus; ALT, alanine aminotransferase; ULN, upper limit of normal; $H C C$, hepatocellular carcinoma; $\geq A 2$, moderate to severe inflammation; $\geq F 2$, significant fibrosis or more; HBeAg, hepatitis $B$ e antigen; tenofovir DF, tenofovir disoproxil fumarate; tenofovir AF, tenofovir alafenamide fumarate; peg-interferon, pegylated interferon.

*APASL recommends the consideration of liver biopsy if noninvasive tests suggest evidence of significant fibrosis, ALT becomes persistently elevated, age is $>35$ years, or there is a family history of HCC or cirrhosis. 


\section{$\mathrm{CHB}$, immune tolerant phase}

Previously, most practice guidelines did not recommend antiviral therapy for CHB patients in the immune tolerant phase (Table 3). ${ }^{17,31}$ Recent data regarding the treatment of $\mathrm{CHB}$ patients in the immune tolerant phase suggest that the risk of progression to liver cirrhosis and HCC development could be reduced by antiviral therapy. ${ }^{13,32}$ Therefore, patients needing treatment should be differentiated from truly immune tolerant CHB patients who do not require antiviral therapy. However, initiation of antiviral therapy for patients in the immune tolerant phase remains very controversial, ${ }^{6-8}$ further studies are needed to appropriately define the immune tolerant phase, as discussed above.

The KASL guidelines suggest liver biopsy if the patient is $\geq 30$ 40 years of age, the serum HBV DNA levels are $<10^{7} \mathrm{IU} / \mathrm{mL}$, a noninvasive fibrosis test shows a range of significant hepatic fibrosis, or ALT is at the borderline of the ULN. ${ }^{9}$ Biopsy findings of moderate to severe inflammation ( $\geq A 2$ ) or significant fibrosis $(\geq F 2)$ are treatment indicators. Age cut-offs for the consideration of liver biopsy or treatment vary among the guidelines and are $>40$ years according to the AASLD, $>30$ years according to the EASL, and $>35$ years according to the APASL. ${ }^{6-8}$ The EASL specifically emphasizes the age; it recommends starting treatment regardless of the severity of histological liver lesions if a patient is $>30$ years of age. ${ }^{7}$ However, this recommendation requires further validation. In other cases, histological criteria should be used to determine when to initiate treatment; these values are the same among the guidelines $(\geq A 2 \text { or } \geq F 2)^{6-9}$

\section{$\mathrm{CHB}$, immune active phase}

Antiviral treatment during the immune active phase decreases the risk of liver cirrhosis, hepatic decompensation, and HCC. ${ }^{25-29}$ Therefore, antiviral therapy is recommended for patients in this phase. The criteria for treatment differ slightly among the guidelines (Table 3). Regarding HBV DNA levels, the KASL, AASLD, and APASL suggest levels of $\geq 20,000 \mathrm{lU} / \mathrm{mL}$ for $\mathrm{HBeAg}$-positive and $\geq 2,000 \mathrm{IU} / \mathrm{mL}$ for $\mathrm{HBeAg}$-negative CHB as treatment indicators if ALT is elevated $>2 \times \mathrm{ULN}^{6-9}$ If the ALT levels are $1-2 \times$ ULN, liver biopsy or noninvasive fibrosis tests are necessary to determine whether treatment should be initiated. ${ }^{6-9}$ The EASL recommends the treatment of patients with HBV DNA $>20,000 \mathrm{IU} / \mathrm{mL}$ and ALT $>2 \times U L N$, regardless of the degree of fibrosis, whereas all patients with HBV DNA $>2,000 \mathrm{IU} / \mathrm{mL}$ and ALT $>1 \times$ ULN require fibrosis assessment before treatment ( $\geq \mathrm{A} 2$ or $\mathrm{F} 2$ ). ${ }^{7}$ Previously, a
3-6 months monitoring period was recommended for HBeAgpositive immune active CHB patients expecting spontaneous HBeAg seroconversion. ${ }^{8,17}$ However, this is currently not recommended by the KASL and international guidelines, with the exception of the APASL, owing to an increased risk of liver failure during the follow-up period. ${ }^{6-9,33}$ Additionally, most guidelines recommend immediate antiviral therapy for patients with acute exacerbation, such as elevation of ALT to $\geq 5-10 \times$ ULN or signs of liver failure. .-9,34 $^{-9.3}$

On the contrary, for $\mathrm{HBeAg}$-negative patients with elevated HBV DNA levels $(\geq 2,000 \mathrm{IU} / \mathrm{mL})$ and normal ALT levels, treatment may be delayed or considered after liver biopsy, because these patients are considered to be in a gray area or transitional zone..$^{6-9}$ The KASL, EASL, and APASL also recommend noninvasive fibrosis tests to assess these patients. ${ }^{6,79}$

\section{$\mathrm{CHB}$, immune inactive phase}

The KASL suggested that the immune inactive phase, which features low HBV DNA levels $(<2,000 \mathrm{IU} / \mathrm{mL})$ and normal ALT, is not an indicator for antiviral therapy. ${ }^{9}$ However, the EASL and APASL recommend considering treatment if there is a family history of HCC or liver cirrhosis or significant histological findings upon liver biopsy. ${ }^{7.8}$ Considering that HBsAg loss is an ideal endpoint for therapy, treatment of CHB in this phase may facilitate HBsAg clearance, ${ }^{35}$ thus, the treatment strategy could be changed in the future.

\section{Compensated liver cirrhosis}

Most guidelines recommend treating compensated liver cirrhosis if the HBV DNA level is $\geq 2,000 \mathrm{IU} / \mathrm{mL}$, regardless of the ALT level. ${ }^{6-9}$ Furthermore, even patients with detectable but low HBV DNA $(<2,000 \mathrm{IU} / \mathrm{mL})$ should be considered for treatment (Table 4). ${ }^{6-9}$ This approach is supported by recent data regarding the decrease in liver-related events induced by NA therapy in cirrhotic patients with low level viremia. ${ }^{36}$

\section{Decompensated liver cirrhosis}

Antiviral therapy should be initiated regardless of the ALT level if serum HBV DNA is detected in patients with decompensated liver cirrhosis. ${ }^{6-9}$ Preferably, all HBsAg-positive decompensated cirrhosis patients should receive antiviral therapy, even if HBV DNA is not detected. However, the benefits of NAs for HBV DNA-unde- 
tected patients require further studies. Liver transplantation should also be considered (Table 4). ${ }^{8}$

\section{WHAT TO CHOOSE: SELECTION OF ANTIVIRAL AGENTS}

\section{Pegylated interferon}

Interferons and oral NAs represent the currently available antiviral agents. ${ }^{5-9,37}$ Among interferons, pegylated interferon (peg-interferon) replaced conventional interferon owing to its onceweekly dosing and improved efficacy. ${ }^{37,38}$ However, various adverse events and the inconvenience associated with the injection of peg-interferon have limited its use despite its unique immune-modulatory actions. ${ }^{37-39}$ Nonetheless, peg-interferon should be considered for a finite duration of treatment achievable by the immune-mediated control of HBV, leading to sustained off-treat- ment responses. ${ }^{37-39}$ Peg-interferon is not preferred in patients with liver cirrhosis due to safety concerns and is contraindicated for decompensated cirrhosis patients by all international guidelines. ${ }^{6-9}$

\section{NAs}

Contrary to interferons, NAs are directly acting antiviral agents that inhibit HBV replication and have no fixed treatment duration. ${ }^{6-9}$ NAs are now widely used for CHB treatment owing to their low incidence of adverse effects as well as convenience. Antiviral resistance was a major drawback of first-generation NAs (lamivudine and adefovir). Resistance was very rare in second-generation NAs (entecavir and tenofovir disoproxil fumarate [tenofovir DF]). ${ }^{40-42}$ Additionally, newer generation drugs (besifovir dipivoxil maleate [besifovir] and tenofovir alafenamide fumarate [tenofovir AF]) have alleviated the safety concerns associated with tenofovir DF (renal and bone toxicity), while maintaining a high genetic barrier

Table 4. Comparison of treatment indicators for patients with liver cirrhosis

\begin{tabular}{|c|c|c|c|c|}
\hline & KASL & AASLD & EASL & APASL \\
\hline \multirow[t]{2}{*}{$\begin{array}{l}\text { Compensated } \\
\text { cirrhosis } \\
\text { 1) Treat } \\
\text { 2) Consider }\end{array}$} & $\begin{array}{l}\text { 1) Treat if } \mathrm{HBV} \text { DNA level is } \\
\geq 2,000 \mathrm{IU} / \mathrm{mL} \text {, regardless } \\
\text { of the ALT level }\end{array}$ & $\begin{array}{l}\text { 1) Treat if HBV DNA is } \\
>2,000 \mathrm{IU} / \mathrm{mL} \text {, regardless } \\
\text { of the ALT level }\end{array}$ & $\begin{array}{l}\text { 1) Treat for any detectable } \\
\text { HBV DNA, regardless of } \\
\text { the ALT levels, in patients } \\
\text { with compensated or } \\
\text { decompensated cirrhosis }\end{array}$ & $\begin{array}{l}\text { 1) Treat if HBV DNA is }>2,000 \\
\mathrm{IU} / \mathrm{mL} \text {, even if the ALT levels } \\
\text { are normal }\end{array}$ \\
\hline & $\begin{array}{l}\text { 2) Treatment can be } \\
\text { considered if HBV DNA } \\
\text { is detectable but low } \\
(<2,000 \mathrm{lU} / \mathrm{mL} \text { ), regardless } \\
\text { of the ALT level }\end{array}$ & $\begin{array}{l}\text { 2) Treat patients with } \\
\text { low level viremia (HBV } \\
\text { DNA }<2,000 \mathrm{IU} / \mathrm{mL}) \text {, } \\
\text { regardless of the } A L T \\
\text { level }\end{array}$ & & $\begin{array}{l}\text { 2) Treatment can be considered } \\
\text { irrespective of HBV DNA and } \\
\text { ALT levels }\end{array}$ \\
\hline \multirow[t]{2}{*}{$\begin{array}{l}\text { Decompensated } \\
\text { cirrhosis } \\
\text { 1) Treat } \\
\text { 2), 3) Consider }\end{array}$} & $\begin{array}{l}\text { 1) Treat with a NA if serum } \\
\text { HBV DNA is detected, } \\
\text { regardless of the ALT level }\end{array}$ & $\begin{array}{l}\text { 1) Treat with antiviral } \\
\text { therapy indefinitely, } \\
\text { regardless of the HBV } \\
\text { DNA level, HBeAg, or } \\
\text { ALT level }\end{array}$ & $\begin{array}{l}\text { 1) Immediately treat with a } \\
\text { NA with high barrier to } \\
\text { resistance, irrespective of } \\
\text { the HBV replication level }\end{array}$ & $\begin{array}{l}\text { 1) Immediately treat with a NA } \\
\text { for patients with detectable } \\
\text { HBV DNA }\end{array}$ \\
\hline & $\begin{array}{l}\text { 2) Consider liver } \\
\text { transplantation }\end{array}$ & $\begin{array}{l}\text { 2) Consider liver } \\
\text { transplantation }\end{array}$ & $\begin{array}{l}\text { 2) Assess for the possibility } \\
\text { of liver transplantation }\end{array}$ & $\begin{array}{l}\text { 2) Consider treatment for } \\
\text { all patients with hepatic } \\
\text { decompensation, irrespective } \\
\text { of HBV DNA levels } \\
\text { 3) Consider liver transplantation }\end{array}$ \\
\hline First-line agents* & $\begin{array}{l}\text { Entecavir, tenofovir DF, } \\
\text { tenofovir } \mathrm{AF}^{\dagger} \text {, besifovir }\end{array}$ & $\begin{array}{l}\text { Entecavir, tenofovir DF, } \\
\text { tenofovir } \mathrm{AF}^{\dagger}\end{array}$ & $\begin{array}{l}\text { Entecavir, tenofovir DF, } \\
\text { tenofovir } \mathrm{AF}^{\dagger}\end{array}$ & Entecavir, tenofovir DF \\
\hline
\end{tabular}

KASL, Korean Association for the Study of the Liver; APASL, Asian-Pacific Association for the Study of the Liver; HBV, hepatitis B virus; ALT, alanine aminotransferase; NA, nucleos(t)ide analog; HBeAg, hepatitis B e antigen; tenofovir DF, tenofovir disoproxil fumarate; tenofovir AF, tenofovir alafenamide fumarate.

*Peg-interferon can only be used, with caution, for compensated cirrhosis, but may not be preferred owing to safety concerns.

${ }^{\dagger}$ Insufficient data for decompensated cirrhosis. 
to resistance. ${ }^{43-45}$ Therefore, the KASL recommends NAs with a high genetic barrier to resistance, including entecavir, tenofovir $D F$, tenofovir $A F$, and besifovir, rather than those with a low genetic barrier to resistance (lamivudine, telbivudine, clevudine, and adefovir) as first-line agents for CHB treatment. ${ }^{9}$

Lamivudine and adefovir have been used for extended periods but are no longer recommended given their low potency and high incidence of resistance. ${ }^{42,46}$ Telbivudine and clevudine are comparable to entecavir in their antiviral potency but are currently not recommended owing to the frequent development of antiviral resistance and serious muscle-related problems. ${ }^{42,46-49}$

Entecavir and tenofovir DF have been the preferred antiviral agents for more than a decade since their approval for CHB treatment. Recently, these drugs were compared in terms of long-term treatment outcomes, especially for the prevention of HCC. $^{50-53}$ The initial report using data from the Korean National Health Insurance Service database suggested that tenofovir DF was associated with a significantly lower risk of HCC compared to entecavir. ${ }^{50}$ However, subsequent reports using multicenter academic teaching hospital data were contradictory and found no difference between the two therapies regarding the incidence of HCC, allcause mortality, and liver transplantation, even after a thorough adjustment of baseline characteristics. ${ }^{51,52}$ The issue remains contentious and requires further longer term and larger scale studies with the appropriate adjustment of possible biases to reach a consensus. $^{53}$

Currently, generic and less expensive forms of entecavir and tenofovir (tenofovir disoproxil or tenofovir fumarate aspartate) are available in Korea and other countries, which can improve the cost-effectiveness of antiviral treatment. ${ }^{54,55}$ Unfortunately, there is limited clinical data on the antiviral efficacy of generic antiviral drugs for $\mathrm{CHB}$. $^{55}$

Tenofovir AF is a nucleotide reverse transcriptase inhibitor and a novel prodrug of tenofovir. It has greater plasma stability than tenofovir DF and efficiently delivers the active form of tenofovir to hepatocytes at a lower dose. ${ }^{44,45}$ In phase 3 clinical trials, tenofovir AF was found to be as effective as tenofovir DF and induced significantly smaller decreases in the estimated glomerular filtration rate and spine/hip bone density than tenofovir DF after up to 96 weeks of treatment. ${ }^{44,45}$

Besifovir is an acyclic nucleotide phosphonate developed in Korea that was approved by the Ministry of Food and Drug Safety in 2017. ${ }^{43}$ However, it is still not available outside Korea. The KASL guidelines are the first to include besifovir as one of the initial choices for CHB treatment. ${ }^{9}$ The advantage of besifovir over teno- fovir DF has been well described. ${ }^{43}$ Briefly, in phase 3 randomized controlled trials, besifovir was comparable to tenofovir DF in terms of antiviral efficacy after 48 weeks of treatment. Additionally, the renal and bone safety profiles of besifovir were superior to those of tenofovir DF. The estimated glomerular filtration rate and hip/ spine bone mineral density were significantly higher in the besifovir group than in the tenofovir DF group. ${ }^{43}$ After 48 weeks, all patients were rolled over into an open-label extensional study where everyone received besifovir. In patients who switched from tenofovir DF to besifovir, the estimated glomerular filtration rate and hip/spine bone mineral density improved to baseline levels at 96 weeks. $^{43}$

Currently, there is limited data regarding the use of besifovir or tenofovir AF in patients with decompensated liver cirrhosis or HCC. However, there seems to be no reason not to use these drugs. In the future, more data regarding besifovir and tenofovir AF will be available for CHB patients in various situations. The AASLD and EASL recommend entecavir, tenofovir DF, and tenofovir $A F$ monotherapy as the preferred regimens for the treatment of CHB and liver cirrhosis patients. The APASL only recommends entecavir and tenofovir DF, likely owing to the limited data available at the time of its publication in $2016 .^{6-8}$

No guidelines recommend a combination of peg-interferon and NA or a combination of NAs as initial therapy due to their limited benefits. ${ }^{6-9}$

\section{WHEN TO CHANGE: TREATMENT MODIFICA- TIONS}

\section{Partial virological responses (PVR)}

Although the antiviral efficacy of drugs has remarkably improved, patients with very high HBV DNA levels may show PVR featuring a decreased but still detectable level of HBV DNA after at least 48 weeks of continued treatment with high genetic barrier drugs. Other causes of PVR include decreased susceptibility owing to previous drug exposure, decreased medication compliance, and altered drug metabolism. The clinical significance of low level viremia due to PVR is unclear although an increased risk of liver-related complications was found in patients with advanced liver diseases. ${ }^{36,56}$

There are slightly different definitions of PVR. They are summarized in Table 5. Briefly, the KASL defines PVR at different time points based on the genetic barrier of the drugs, at 48 weeks of 
therapy for high genetic barrier drugs and at 24 weeks for low genetic barrier drugs. ${ }^{9}$ The APASL defines PVR as detectable HBV DNA at 24 weeks of therapy, whereas the EASL and AASLD define PVR or persistent viremia at 48 weeks and 96 weeks of entecavir or tenofovir treatment, respectively. ${ }^{6-8}$

Modification of therapy may be considered for PVR, especially when using low genetic barrier drugs (Table 5). However, the recommendations for managing PVR during entecavir or tenofovir DF therapy are not consistent across the guidelines (Table 5). All guidelines indicate that high genetic barrier drugs can be continued, with the possibility of switching to another high genetic barrier drug (KASL, EASL) or add-on (EASL), especially in patients with advanced liver diseases. ${ }^{6.9}$ The AASLD argues that there is insufficient comparative evidence to advocate the addition of a second drug or switching to another drug. However, a recent randomized controlled trial compared switching to tenofovir DF with continuation of entecavir for the treatment of CHB with PVR and observed a better virological outcome upon switching to tenofovir DF. ${ }^{57}$ Hence, the KASL recommends switching to tenofovir DF for patients with entecavir PVR. ${ }^{9}$

\section{Antiviral resistance}

Although antiviral resistance is uncommon in previously treatment-naïve patients receiving high genetic barrier drugs, entecavir resistance was found in 1-3\% of patients, and variants resistant to tenofovir DF have been identified. ${ }^{40,42,58,59}$ Entecavir resistance rates increase up to $50 \%$ in the fifth year in treatment-experienced or refractory patients. ${ }^{40,42}$ Adefovir monotherapy also has a high risk of resistance in patients with lamivudine resistance with up to $25 \%$ resistance at two years of treatment, leading to multidrug resistance. ${ }^{60,61}$ The collective findings highlight the importance of paying attention to patients' adherence to medication; antiviral resistance testing should be performed in case of virological breakthrough. ${ }^{42}$

After antiviral resistance is confirmed, it is assumed that one of two strategies can be applied: switching to another class of antiviral monotherapy with a high genetic barrier to resistance or adding a second antiviral drug that lacks cross-resistance (Table 6). The recent KASL guidelines recommend that patients with resistance to L-nucleoside analogs (lamivudine and telbivudine) be

Table 5. Comparison of partial virological response management during chronic hepatitis B treatment

\begin{tabular}{|c|c|c|c|c|}
\hline & KASL & AASLD & EASL & APASL \\
\hline Definition & $\begin{array}{l}\text { A decreased but detectable } \\
\text { level of HBV DNA after at } \\
\text { least } 48 \text { weeks of therapy } \\
\text { using high genetic barrier } \\
\text { drugs ( } 24 \text { weeks for low } \\
\text { genetic barrier drugs) }\end{array}$ & $\begin{array}{l}\text { Persistent viremia is defined } \\
\text { as a plateau in the decline } \\
\text { of HBV DNA and/or failure } \\
\text { to achieve an undetectable } \\
\text { HBV DNA level after } 96 \\
\text { weeks of therapy }\end{array}$ & $\begin{array}{l}\text { A decrease in HBV DNA } \\
\text { level of more than } \\
1 \log _{10} \mathrm{IU} / \mathrm{mL} \text { but } \\
\text { HBV DNA remains } \\
\text { detectable after at least } \\
12 \text { months of therapy }\end{array}$ & $\begin{array}{l}\text { Reduction of serum HBV } \\
\text { DNA level }>1 \log \mathrm{IU} / \mathrm{mL} \\
\text { but still detectable at } \\
24 \text { weeks of therapy }\end{array}$ \\
\hline $\begin{array}{l}\text { PVR to low genetic barrier } \\
\text { (e.g., lamivudine or } \\
\text { telbivudine) } \\
\text { 1) Switch }\end{array}$ & $\begin{array}{l}\text { 1) Switch: switching to NAs } \\
\text { with high genetic barriers } \\
\text { and no cross-resistance is } \\
\text { recommended }\end{array}$ & - & - & $\begin{array}{l}\text { 1) Switch: treatment can } \\
\text { be modified }\end{array}$ \\
\hline \multirow[t]{2}{*}{$\begin{array}{l}\text { PVR to high genetic } \\
\text { barrier (e.g., entecavir or } \\
\text { tenofovir) } \\
\text { 1) Continue } \\
\text { 2) Switch/add }\end{array}$} & $\begin{array}{l}\text { 1) Continue: treatment can } \\
\text { be continued }\end{array}$ & $\begin{array}{l}\text { 1) Continue: patients with } \\
\text { persistent low level viremia } \\
\text { (HBV DNA }<2,000 \mathrm{IU} / \mathrm{mL} \text { ) } \\
\text { on entecavir or tenofovir } \\
\text { may continue treatment }\end{array}$ & $\begin{array}{l}\text { 1) Continue: patients } \\
\text { with declining serum } \\
\text { HBV DNA levels may } \\
\text { continue treatment } \\
\text { with the same agent }\end{array}$ & $\begin{array}{l}\text { 1) Continue: for patients } \\
\text { with detectable HBV } \\
\text { DNA after } 24 \text { weeks, } \\
\text { continuation of the } \\
\text { same treatment is } \\
\text { recommended }\end{array}$ \\
\hline & $\begin{array}{l}\text { 2) Switch: switching } \\
\text { to tenofovir is } \\
\text { recommended in the } \\
\text { case of partial virological } \\
\text { response to entecavir }\end{array}$ & & $\begin{array}{l}\text { 2) Switch or add: in } \\
\text { cases where HBV } \\
\text { DNA levels plateau, a } \\
\text { switch to another drug } \\
\text { or a combination of } \\
\text { entecavir/tenofovir can } \\
\text { be considered }\end{array}$ & \\
\hline
\end{tabular}

KASL, Korean Association for the Study of the Liver; AASLD, American Association for the Study of Liver Diseases; EASL, European Association for the Study of the Liver; APASL, Asian-Pacific Association for the Study of the Liver; HBV, hepatitis B virus; PVR, partial virological responses; NA, nucleos(t)ide analog. 
switched to tenofovir DF/AF. ${ }^{9}$ For adefovir or entecavir resistance, switching to tenofovir DF/AF monotherapy or a combination of tenofovir DF/AF and entecavir is recommended. For multidrug resistance, switching to a combination of tenofovir DF/AF and entecavir or tenofovir DF/AF monotherapy is recommended. ${ }^{9}$ Similar recommendations were provided by the AASLD, EASL, and APASL favoring tenofovir DF/AF monotherapy, except in cases of multidrug resistance..$^{6-8}$ However, considering recent reports of the long-term efficacy of tenofovir DF for multidrug resistance, tenofovir DF/AF monotherapy could also be a safe option. ${ }^{62,63}$

There are insufficient data regarding tenofovir resistance, although guidelines recommend adding or switching to entecavir. In these cases, it is likely that new antiviral agents other than NAs, such as capsid assembly inhibitors, may be needed. ${ }^{58}$

\section{Adverse effects}

NAs are relatively safe drugs, even with long-term use. Howev- er, all drugs may have side effects. Clinically significant adverse effects associated with NA therapy include lactic acidosis (entecavir, tenofovir DF, adefovir, lamivudine, and telbivudine), nephropathy, osteomalacia, Fanconi syndrome (tenofovir DF and adefovir), increasing low-density lipoprotein cholesterol (tenofovir AF), carnitine depletion (besifovir), pancreatitis (lamivudine), peripheral neuropathy, creatinine kinase elevation, and myopathy (telbivudine and clevudine). ${ }^{9}$ When NA-related adverse effects are suspected, it is essential to confirm the diagnosis. In cases of serious complications, immediate cessation of the drug or switching to another drug should be considered. For example, switching to entecavir or tenofovir DF is a reasonable option for clevudine- or telbivudine-associated myopathy. $48,49,64$

Among the high genetic barrier drugs preferred as first-line agents for CHB treatment, tenofovir DF has an increased risk of renal and bone toxicity. ${ }^{65}$ The KASL recommends substituting tenofovir DF with entecavir, tenofovir AF, or besifovir in such patients based on previous treatment history. ${ }^{9}$ The AASLD and EASL

Table 6. Comparison of antiviral resistance management during chronic hepatitis B treatment

\begin{tabular}{|c|c|c|c|c|}
\hline & $\mathrm{KASL}^{*}$ & AASLD* & EASL & APASL \\
\hline $\begin{array}{l}\text { Lamivudine/telbivudine } \\
\text { resistance } \\
\text { 1) Switch }\end{array}$ & $\begin{array}{l}\text { 1) Switch to tenofovir } \\
\text { (TDF or TAF) }\end{array}$ & $\begin{array}{l}\text { 1) Switch to tenofovir } \\
\text { (TDF or TAF) }\end{array}$ & $\begin{array}{l}\text { 1) Switch to tenofovir } \\
\text { (TDF or TAF) }\end{array}$ & 1) Switch to TDF \\
\hline \multirow{2}{*}{$\begin{array}{l}\text { Entecavir resistance } \\
\text { 1) Switch } \\
\text { 2) Combine }\end{array}$} & $\begin{array}{l}\text { 1) Switch to tenofovir } \\
\text { (TDF or TAF) }\end{array}$ & \multirow[t]{2}{*}{$\begin{array}{l}\text { 1) Switch to tenofovir } \\
\text { (TDF or TAF) }\end{array}$} & \multirow[t]{2}{*}{$\begin{array}{l}\text { 1) Switch to tenofovir } \\
\text { (TDF or TAF) }\end{array}$} & \multirow[t]{2}{*}{ 1) Switch to TDF } \\
\hline & $\begin{array}{l}\text { 2) Combine with tenofovir } \\
\text { (TDF or TAF) }\end{array}$ & & & \\
\hline \multirow[t]{2}{*}{$\begin{array}{l}\text { Adefovir resistance } \\
\text { 1) Switch } \\
\text { 2) Switch/combine }\end{array}$} & $\begin{array}{l}\text { 1) Switch to tenofovir } \\
\text { (TDF or TAF) }\end{array}$ & \multirow[t]{2}{*}{$\begin{array}{l}\text { 1) Switch to ETV or } \\
\text { tenofovir (TDF or TAF) }\end{array}$} & $\begin{array}{l}\text { 1) Switch to ETV or } \\
\text { tenofovir (TDF or TAF) } \\
\text { (LAM-naïve) }\end{array}$ & $\begin{array}{l}\text { 1) Switch to either ETV } \\
\text { or TDF (no LAM- } \\
\text { resistance) }\end{array}$ \\
\hline & $\begin{array}{l}\text { 2) Combine ETV plus } \\
\text { tenofovir (TDF or TAF) }\end{array}$ & & $\begin{array}{l}\text { 2) Switch to tenofovir (TDF } \\
\text { or TAF) (LAM-resistance) } \\
\text { If HBV DNA plateaus: } \\
\text { combine ETV or switch } \\
\text { to ETV }\end{array}$ & $\begin{array}{l}\text { 2) Switch to TDF } \\
\text { monotherapy (LAM- } \\
\text { resistance) }\end{array}$ \\
\hline \multirow{2}{*}{$\begin{array}{l}\text { Tenofovir resistance } \\
\text { 1) Combine/switch } \\
\text { 2) Combine }\end{array}$} & 1) Combine with ETV & \multirow[t]{2}{*}{ 1) Switch to ETV } & $\begin{array}{l}\text { 1) Switch to ETV (LAM- } \\
\text { naïve) }\end{array}$ & \multirow[t]{2}{*}{ - } \\
\hline & & & $\begin{array}{l}\text { 2) Combine with ETV } \\
\text { (LAM-resistance) }\end{array}$ & \\
\hline \multirow{2}{*}{$\begin{array}{l}\text { Multidrug resistance } \\
\text { 1) Combine } \\
\text { 2) Switch }\end{array}$} & $\begin{array}{l}\text { 1) Combine ETV and } \\
\text { tenofovir (TDF or TAF) }\end{array}$ & \multirow[t]{2}{*}{$\begin{array}{l}\text { 1) Combine ETV and } \\
\text { tenofovir (TDF or TAF) }\end{array}$} & \multirow[t]{2}{*}{$\begin{array}{l}\text { 1) Combine ETV and } \\
\text { tenofovir (TDF or TAF) }\end{array}$} & \multirow[t]{2}{*}{ 1) Combine ETV and TDF } \\
\hline & $\begin{array}{l}\text { 2) Switch to tenofovir } \\
\text { (TDF or TAF) }\end{array}$ & & & \\
\hline
\end{tabular}

KASL, Korean Association for the Study of the Liver; AASLD, American Association for the Study of Liver Diseases; EASL, European Association for the Study of the Liver; APASL, Asian-Pacific Association for the Study of the Liver; TDF, tenofovir disoproxil fumarate; TAF, tenofovir alafenamide fumarate; LAM, lamivudine; HBV, hepatitis B virus; ETV, entecavir.

*Preferred treatment was suggested. 
also recommend that patients using tenofovir DF who are at risk of developing and/or have underlying renal dysfunction or metabolic bone disease consider switching to entecavir or tenofovir AF, depending on their previous lamivudine exposure. ${ }^{6,7}$ For lamivudine or other NA-experienced or refractory patients, tenofovir AF is preferred to entecavir.

\section{WHEN TO STOP: TREATMENT CESSATION}

The standard duration of peg-interferon therapy is 48 weeks for HBeAg-positive or -negative CHB. ${ }^{38,66}$ Thus, it would be acceptable to stop treatment after the planned schedule is completed. Extending the treatment duration may be more effective for
HBeAg-negative $\mathrm{CHB}^{67,68}$ but cannot be routinely recommended (Table 7).

There is no predefined duration for NA therapy. As such, stopping NAs before achieving the ultimate goal of antiviral therapy, which is the improvement of survival by the prevention of liver disease progression and HCC development, ${ }^{7-9}$ may lead to the loss of treatment benefits and risk clinical exacerbations. Therefore, appropriate biomarkers are needed for proper decision making regarding cessation of NA therapy.

\section{HBeAg-positive CHB}

Previously, HBeAg loss or seroconversion was considered an indication to stop therapy in HBeAg-positive CHB. ${ }^{17,69}$ Cessation of

Table 7. Comparison of cessation criteria for chronic hepatitis B treatment

\begin{tabular}{|c|c|c|c|c|}
\hline & KASL & AASLD & EASL & APASL \\
\hline \multicolumn{5}{|l|}{ NAs } \\
\hline \multirow[t]{2}{*}{$\begin{array}{l}\text { HBeAg- } \\
\text { postive } \\
\text { CHB }\end{array}$} & 1) HBsAg loss & $\begin{array}{l}\text { 1) HBeAg seroconversion } \\
\text { with } 12 \text { months } \\
\text { consolidation plus } \\
\text { undetectable HBV DNA }\end{array}$ & $\begin{array}{l}\text { 1) HBsAg loss with/without } \\
\text { anti-HB seroconversion }\end{array}$ & $\begin{array}{l}\text { 1) HBeAg seroconversion with } \\
12 \text { months consolidation } \\
\text { (preferably } 3 \text { years) }\end{array}$ \\
\hline & $\begin{array}{l}\text { 2) HBeAg loss/seroconversion } \\
\text { with } 12 \text { months } \\
\text { consolidation plus } \\
\text { undetectable HBV DNA }\end{array}$ & $\begin{array}{l}\text { 2) Alternatively, treat until } \\
\text { HBsAg is lost }\end{array}$ & $\begin{array}{l}\text { 2) HBeAg seroconversion } \\
\text { with } 12 \text { months } \\
\text { consolidation plus } \\
\text { undetectable HBV DNA }\end{array}$ & 2) HBsAg loss or seroconversion \\
\hline \multirow{2}{*}{$\begin{array}{l}\text { HBeAg- } \\
\text { negative } \\
\text { CHB }\end{array}$} & 1) HBsAg loss & 1) Indefinite & $\begin{array}{l}\text { 1) HBsAg loss with/without } \\
\text { seroconversion }\end{array}$ & 1) HBsAg loss or seroconversion \\
\hline & & $\begin{array}{l}\text { 2) May be considered after } \\
\text { HBsAg loss }\end{array}$ & $\begin{array}{l}\text { 2) May be considered after } \\
\text { long-term ( } \geq 3 \text { years) } \\
\text { virological suppression } \\
\text { after NA therapy }\end{array}$ & $\begin{array}{l}\text { 2) Undetectable HBV DNA for } \\
\text { at least } 2 \text { years on } 3 \text { separate } \\
\text { occasions each } 6 \text { months apart }\end{array}$ \\
\hline \multirow[t]{2}{*}{ Liver cirrhosis } & $\begin{array}{l}\text { 1) Long-term treatment for } \\
\text { compensated cirrhosis }\end{array}$ & $\begin{array}{l}\text { 1) Indefinite (may be } \\
\text { considered after HBsAg } \\
\text { loss) }\end{array}$ & 1) Indefinite & $\begin{array}{l}\text { 1) NA therapy should be continued } \\
\text { for life in compensated and } \\
\text { decompensated cirrhotic } \\
\text { patients }\end{array}$ \\
\hline & $\begin{array}{l}\text { 2) Indefinite for } \\
\text { decompensated cirrhosis }\end{array}$ & & & \\
\hline \multicolumn{5}{|l|}{ Peg-Interferon } \\
\hline HBeAg $(+)$ & 48 weeks & 48 weeks & 48 weeks & 48 weeks \\
\hline \multirow[t]{2}{*}{ HBeAg (-) } & 48 weeks & 48 weeks & 1) 48 weeks & 48 weeks \\
\hline & & & $\begin{array}{l}\text { 2) Extending treatment } \\
\text { beyond } 48 \text { weeks may be } \\
\text { beneficial }\end{array}$ & \\
\hline
\end{tabular}

1) Preferred, 2) alternative.

KASL, Korean Association for the Study of the Liver; AASLD, American Association for the Study of Liver Diseases; EASL, European Association for the Study of the Liver; APASL, Asian-Pacific Association for the Study of the Liver; NA, nucleos(t)ide analog; HBeAg, hepatitis B e antigen; CHB, chronic hepatitis B; HBV, hepatitis B virus; $\mathrm{HBsAg}$, hepatitis B surface antigen; peg-interferon, pegylated interferon. 
antiviral therapy was recommended after 12 months of consolidation therapy. However, most patients experienced virological or clinical relapse. On the contrary, HBsAg loss or seroconversion is rare during antiviral therapy, but the prognosis of patients who cleared HBsAg is much improved; relapse of viral replication is very rare, and liver transplant-free survival or HCC-free survival is significantly better than for those who did not clear HBsAg. ${ }^{22}$ Based on this information, the KASL and EASL guidelines suggest that HBsAg loss is the ideal endpoint of therapy and should be the primary goal. ${ }^{7.9}$ Still, the AASLD and APASL consider HBeAg seroconversion as a satisfactory endpoint, probably owing to the rarity of HBsAg loss (Table 7). ${ }^{6.8}$

\section{HBeAg-negative CHB}

Relapse is common after stopping antiviral therapy in HBeAgnegative CHB patients owing to the presence of immune escape mutants. ${ }^{70}$ Therefore, the AASLD suggests that treatment may be continued indefinitely or until HBsAg is lost. ${ }^{6}$ The KASL and EASL also suggest the cessation of NAs after HBsAg loss (Table 7). ${ }^{7,9}$ However, the EASL also proposed that NA discontinuation may be considered in select patients with long-term ( $\geq 3$ years) virological suppression under NAs. ${ }^{7}$ Similarly, the APASL suggested that treatment be withdrawn after $\mathrm{HBsAg}$ loss following either anti-HB seroconversion or at least 12 months of consolidation therapy. Otherwise, at least $\geq 2$ years of consolidation therapy confirming undetectable HBV DNA levels on three separate occasions can justify the end of treatment (Table 7). ${ }^{8}$ However, undetectable HBV DNA levels cannot likely be the sole factor in determining treatment cessation because most patients experience virological relapse after stopping therapy in the presence of $\mathrm{HBsAg}{ }^{70,71}$ Recently, a low HBsAg titer $(<2 \log \mathrm{IU} / \mathrm{mL}$ ) was proposed as an indicator of safe cessation of therapy before HBsAg loss, although further clinical experience may be necessary. ${ }^{72,73}$

\section{Liver cirrhosis}

For patients with compensated or decompensated cirrhosis, indefinite therapy is recommended by most guidelines (Table 7). ${ }^{6-9}$ However, NA therapy may be discontinued after HBsAg loss or seroconversion in cases of compensated cirrhosis.

\section{CONSIDERATIONS FOR SPECIAL POPULA- TIONS}

CHB patients may face situations requiring special consideration. HCC may develop, accompanying renal or bone abnormalities may be detected, and anticancer chemotherapy or immunosuppressive therapy may be needed. Table 8 summarizes representative special conditions and compares international guidelines.

\section{Renal dysfunction or metabolic bone disease}

Patients who develop renal dysfunction or decreased bone density during tenofovir DF or adefovir treatment may need to change medication, as described above concerning adverse effects. ${ }^{65}$ If a treatment-naïve patient has pre-existing renal dysfunction (estimated glomerular filtration $<60 \mathrm{~min} / \mathrm{mL} / 1.73 \mathrm{~m}^{2}$, dipstick proteinuria, urine albuminuria/creatinine $>30 \mathrm{mg} / \mathrm{g}$, or serum phosphate $<2.5 \mathrm{mg} / \mathrm{dL}$ ) or metabolic bone disease (chronic steroid use, taking medication that worsens bone density, or pre-existing osteoporosis/osteopenia) before starting the therapy, entecavir, tenofovir AF, and besifovir are preferred for treatment by the KASL. Although the AASLD previously suggested that there was no preference between entecavir or tenofovir DF regarding the potential long-term risk of renal and bone complications, ${ }^{74}$ their updated guidance recommends switching to tenofovir AF or entecavir if tenofovir DF-associated renal dysfunction or bone disease is suspected. ${ }^{6}$ The EASL made detailed recommendations regarding renal or bone abnormalities in terms of when to consider entecavir or tenofovir AF over tenofovir DF when initiating antiviral therapy. ${ }^{7}$ Similar criteria have been proposed by the KASL, as described above (Table 8). The EASL also included age $>60$ years, history of fragility fracture, and hemodialysis for similar candidates, but individualized approaches are needed. 'These criteria must be clinically validated further. ${ }^{7}$ The NA doses in all patients with renal dysfunction should be adjusted according to their creatinine clearance. ${ }^{9}$

\section{HCC}

Only the KASL and APASL have recommendations for patients with HBV-related HCC (Table 8). ${ }^{89}$ Given that HCC is one of the most serious complications in CHB patients, appropriate measures should be taken. Importantly, antiviral therapy reduces both the incidence of de novo HCC and the recurrence of HCC in this population. ${ }^{25-29,75-77}$ Furthermore, the reactivation of HBV can be effec- 
Hyung Joon Yim, et al.

Comparison of $\mathrm{CHB}$ guidelines

Table 8. Comparison of chronic hepatitis B management for special populations

\begin{tabular}{|c|c|c|c|c|}
\hline & KASL & AASLD & EASL & APASL \\
\hline \multirow[t]{2}{*}{$\begin{array}{l}\text { Renal or bone disease } \\
\text { 1) Selection } \\
\text { 2) Switch }\end{array}$} & $\begin{array}{l}\text { 1) Entecavir, TAF, and } \\
\text { besifovir are preferred }\end{array}$ & $\begin{array}{l}\text { 1) No preference between } \\
\text { entecavir or TDF regarding } \\
\text { the potential long-term } \\
\text { risk of renal and bone } \\
\text { complications } \\
\text { TAF is associated with } \\
\text { fewer bone and renal } \\
\text { abnormalities than TDF }\end{array}$ & $\begin{array}{l}\text { 1) Entecavir or TAF are } \\
\text { preferred over TDF for } \\
\text { patients with increasing } \\
\text { age ( }>60 \text { years), bone } \\
\text { diseases, or renal } \\
\text { alterations }\end{array}$ & $\begin{array}{l}\text { 1) Entecavir or telbivudine } \\
\text { are the first-line treatment } \\
\text { options for chronic HBV- } \\
\text { infected patients with any } \\
\text { level of renal dysfunction } \\
\text { and renal replacement } \\
\text { therapy }\end{array}$ \\
\hline & $\begin{array}{l}\text { 2) Treatment can be } \\
\text { switched to TAF, besifovir, } \\
\text { or entecavir in high risk } \\
\text { patients }\end{array}$ & $\begin{array}{l}\text { 2) TDF should be substituted } \\
\text { with TAF or entecavir } \\
\text { for TDF-associated renal } \\
\text { dysfunction and/or bone } \\
\text { disease }\end{array}$ & $\begin{array}{l}\text { 2) Switching to entecavir or } \\
\text { TAF should be considered } \\
\text { for patients on TDF at risk } \\
\text { of development and/or } \\
\text { with underlying renal or } \\
\text { bone disease }\end{array}$ & $\begin{array}{l}\text { 2) Renal function and } \\
\text { bone profiles should be } \\
\text { monitored at least every } \\
3 \text { months if TDF or ADV is } \\
\text { used }\end{array}$ \\
\hline $\begin{array}{l}\text { HCC } \\
\text { 1) Treat } \\
\text { 2) Prophylaxis }\end{array}$ & $\begin{array}{l}\text { 1) Antiviral therapy should } \\
\text { be initiated in patients } \\
\text { with HBV-related HCC } \\
\text { if serum HBV DNA is } \\
\text { detected } \\
\text { 2) Prophylactic antiviral } \\
\text { therapy should be } \\
\text { considered in patients } \\
\text { undergoing anticancer } \\
\text { treatment, regardless of } \\
\text { serum HBV DNA levels }\end{array}$ & - & - & $\begin{array}{l}\text { 1) NA treatment should be } \\
\text { given to patients with } \\
\text { HBV-related HCC (at least } \\
\text { 1-2 weeks before, during, } \\
\text { and after chemotherapy, } \\
\text { locoregional therapies, } \\
\text { resection, or liver } \\
\text { transplantation), if there } \\
\text { is detectable serum HBV } \\
\text { DNA }\end{array}$ \\
\hline \multirow[t]{2}{*}{$\begin{array}{l}\text { Immunosuppression } \\
\text { or chemotherapy } \\
\text { 1) Prophylaxis } \\
\text { (HBsAg-positive) } \\
\text { 2) Monitor/treat/ } \\
\text { prophylaxis } \\
\text { (HBsAg-negative) }\end{array}$} & $\begin{array}{l}\text { 1) If either HBsAg is } \\
\text { positive or HBV DNA is } \\
\text { detected, prophylactic } \\
\text { antiviral therapy should } \\
\text { be initiated before } \\
\text { immune-suppression or } \\
\text { chemotherapy }\end{array}$ & $\begin{array}{l}\text { 1) Anti-HBV prophylaxis } \\
\text { should be initiated in } \\
\text { HBsAg-positive anti- } \\
\text { HBc-positive patients } \\
\text { before starting } \\
\text { immunosuppressive or } \\
\text { cytotoxic therapy }\end{array}$ & $\begin{array}{l}\text { 1) All HBsAg-positive } \\
\text { patients should receive } \\
\text { ETV, TDF, or TAF as } \\
\text { treatment or prophylaxis }\end{array}$ & $\begin{array}{l}\text { 1) Prophylactic antiviral } \\
\text { therapy should be } \\
\text { administered in anti-HBc- } \\
\text { positive patients with } \\
\text { either HBsAg-positive or } \\
\text { detectable serum HBV } \\
\text { DNA }\end{array}$ \\
\hline & $\begin{array}{l}\text { 2) HBsAg-negative anti-HBc- } \\
\text { positive patients with } \\
\text { undetectable HBV DNA } \\
\text { should be monitored } \\
\text { for serum HBsAg } \\
\text { and HBV DNA during } \\
\text { immunosuppression/ } \\
\text { chemotherapy and NAs } \\
\text { should be initiated if HBV } \\
\text { reactivation occurs } \\
\text { If rituximab is included, } \\
\text { initiate antiviral } \\
\text { therapy at the start of } \\
\text { immunosuppression or } \\
\text { chemotherapy }\end{array}$ & $\begin{array}{l}\text { 2) HBsAg-negative anti-HBc- } \\
\text { positive patients should } \\
\text { be carefully monitored for } \\
\text { ALT, HBV DNA, and HBsAg } \\
\text { to provide therapy as } \\
\text { needed } \\
\text { For patients receiving } \\
\text { anti-CD20 antibody } \\
\text { therapy (e.g., rituximab) } \\
\text { or undergoing stem } \\
\text { cell transplantation, } \\
\text { anti-HBV prophylaxis is } \\
\text { recommended }\end{array}$ & $\begin{array}{l}\text { 2) HBsAg-negative anti- } \\
\text { HBc-positive patients } \\
\text { should receive anti- } \\
\text { HBV prophylaxis if they } \\
\text { are at high risk of HBV } \\
\text { reactivation }\end{array}$ & $\begin{array}{l}\text { 2) HBsAg-negative anti-HBc- } \\
\text { positive patients with } \\
\text { undetectable serum HBV } \\
\text { DNA levels who receive } \\
\text { chemotherapy and/ } \\
\text { or immunosuppression } \\
\text { should be carefully } \\
\text { monitored and be treated } \\
\text { with NAs upon HBV } \\
\text { reactivation }\end{array}$ \\
\hline
\end{tabular}




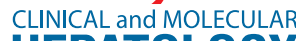

\section{HEPATOLOGY}

Volume_26 Number_4 October 2020

Table 8. Continued

\begin{tabular}{|c|c|c|c|c|}
\hline & KASL & AASLD & EASL & APASL \\
\hline \multirow[t]{3}{*}{$\begin{array}{l}\text { Pregnant women } \\
\text { 1) Treat/switch } \\
\text { 2) Prevention } \\
\text { 3) Lactation }\end{array}$} & $\begin{array}{l}\text { 1) Initiate or switch to TDF if } \\
\text { treatment is needed }\end{array}$ & 1) TDF is preferred & $\begin{array}{l}\text { 1) TDF should be continued, } \\
\text { whereas ETV or other NAs } \\
\text { should be switched to } \\
\text { TDF }\end{array}$ & $\begin{array}{l}\text { 1) TDF is the drug of choice } \\
\text { for mothers requiring } \\
\text { antiviral treatment }\end{array}$ \\
\hline & $\begin{array}{l}\text { 2) For pregnant women } \\
\text { with serum HBV DNA } \\
\text { levels }>200,000 \mathrm{IU} / \mathrm{mL} \text {, } \\
\text { TDF administration is } \\
\text { recommended to prevent } \\
\text { MTCT, beginning at } 24-32 \\
\text { weeks of gestation and } \\
\text { stopping } 2-12 \text { weeks after } \\
\text { delivery }\end{array}$ & $\begin{array}{l}\text { 2) If HBV DNA }>200,000 \\
\text { IU/mL at 28-32 weeks } \\
\text { of gestation, antiviral } \\
\text { therapy is recommended } \\
\text { to reduce the risk of } \\
\text { perinatal transmission }\end{array}$ & $\begin{array}{l}\text { 2) In all pregnant women } \\
\text { with high HBV DNA levels } \\
\text { (>200,000 IU/mL) or } \\
\text { HBsAg levels }>4 \log _{10} \\
\text { IU/mL, antiviral } \\
\text { prophylaxis with TDF } \\
\text { should begin at } 24-28 \\
\text { weeks of gestation and } \\
\text { continue for up to } 12 \\
\text { weeks after delivery }\end{array}$ & $\begin{array}{l}\text { 2) For pregnant women } \\
\text { with } \mathrm{HBV} \text { DNA }>6-7 \\
\log _{10} \mathrm{IU} / \mathrm{mL} \text {, short-term } \\
\text { maternal NA therapy with } \\
\text { tenofovir or telbivudine is } \\
\text { recommended beginning } \\
\text { at } 28-32 \text { weeks of } \\
\text { gestation }\end{array}$ \\
\hline & $\begin{array}{l}\text { 3) TDF, which is relatively } \\
\text { safe for the fetus and } \\
\text { pregnant women, is not } \\
\text { contraindicated during } \\
\text { breastfeeding }\end{array}$ & $\begin{array}{l}\text { 3) Breastfeeding is not } \\
\text { contraindicated, but there } \\
\text { are insufficient long-term } \\
\text { safety data in infants born } \\
\text { to mothers who received } \\
\text { antiviral agents during } \\
\text { pregnancy and while } \\
\text { breastfeeding }\end{array}$ & $\begin{array}{l}\text { 3) Breast feeding is not } \\
\text { contraindicated in HBsAg- } \\
\text { positive untreated } \\
\text { women or on TDF-based } \\
\text { treatment or prophylaxis }\end{array}$ & $\begin{array}{l}\text { 3) Breast feeding is } \\
\text { discouraged during } \\
\text { maternal NA treatment }\end{array}$ \\
\hline $\begin{array}{l}\text { Acute hepatitis B } \\
\text { 1) Treat }\end{array}$ & $\begin{array}{l}\text { 1) In patients with severe } \\
\text { acute hepatitis B (e.g., } \\
\text { coagulopathy, severe } \\
\text { jaundice, liver failure), NA } \\
\text { therapy can be initiated }\end{array}$ & $\begin{array}{l}\text { 1) Indicators for antiviral } \\
\text { therapy are total bilirubin } \\
>3 \mathrm{mg} / \mathrm{dL} \text {, international } \\
\text { normalized ratio }>1.5 \text {, } \\
\text { encephalopathy, or } \\
\text { ascites }\end{array}$ & $\begin{array}{l}\text { 1) Patients with severe acute } \\
\text { hepatitis B, characterized } \\
\text { by coagulopathy or } \\
\text { protracted course, should } \\
\text { be treated with NAs } \\
\text { and considered for liver } \\
\text { transplantation }\end{array}$ & $\begin{array}{l}\text { 1) Treatment is only } \\
\text { indicated for patients } \\
\text { with fulminant hepatitis B } \\
\text { or for those with severe or } \\
\text { protracted acute hepatitis } \\
\text { B }\end{array}$ \\
\hline
\end{tabular}

KASL, Korean Association for the Study of the Liver; AASLD, American Association for the Study of Liver Diseases; EASL, European Association for the Study of the Liver; APASL, Asian-Pacific Association for the Study of the Liver; TAF, tenofovir alafenamide fumarate; TDF, tenofovir disoproxil fumarate; HBV, hepatitis B virus; ADV, adefovir; HCC, hepatocellular carcinoma; NA, nucleos(t)ide analog; HBeAg, hepatitis B e antigen; anti-HBC, antibody to hepatitis B core antigen; ALT, alanine aminotransferase; ETV, entecavir; MTCT, mother-to-child transmission.

tively prevented by prophylactic antiviral therapy during anticancer treatment. ${ }^{78,79}$ Therefore, the KASL recommends starting NAs before and during HCC treatment if HBV DNA is detected or prophylactically, even if HBV DNA is not detected. ${ }^{9}$ All HBsAg-positive patients should receive NAs after HCC diagnosis, regardless of HBV DNA detection, but this requires confirmation in future studies.

\section{Immunosuppression or chemotherapy}

Patients with chronic HBV infection are at an increased risk of hematological and solid malignancies. ${ }^{80,81}$ Therefore, the chance of receiving immunosuppression or anticancer chemotherapy is relatively high in CHB patients. If the immune system is suppressed by immunosuppression or chemotherapy, HBV can reacti- vate and lead to severe hepatic injury via the acute exacerbation of chronic HBV infection in $\mathrm{HBsAg}$-positive patients or relapse of past HBV infection in HBsAg-negative/anti-HBc-positive patients. ${ }^{82-84} \mathrm{HBV}$ reactivation during anticancer chemotherapy has occurred in $41-53 \%$ of HBsAg-positive anti-HBc-positive patients and in $8-18 \%$ of HBsAg-negative anti-HBc-positive patients. ${ }^{6,85,86}$ If reactivation occurs, dose reduction or discontinuation of anticancer therapy is necessary, which adversely affects the outcomes of cancer treatment. As such, HBsAg and anti-HBc testing should be performed in all patients before initiating any immunosuppressive or cytotoxic chemotherapy. ${ }^{6-9}$ Additionally, particular caution should be exercised with high risk ( $>10 \%$ of reactivation) treatments using B cell-depleting agents (rituximab, ofatumumab, natalizumab, alemtuzumab, and ibritumomab), high-dose corticoste- 
Hyung Joon Yim, et al.

Comparison of $\mathrm{CHB}$ guidelines

roids (prednisone $\geq 20 \mathrm{mg} /$ day, $\geq 4$ weeks), anthracyclines (doxorubicin and epirubicin), potent tumor necrosis factor-alpha inhibitors (infliximab, adalimumab, certolizumab, and golimumab), and local therapy for HCC (transcatheter arterial chemoembolization). ${ }^{9,87}$ High (>10\%), moderate (1-10\%), and low $(<1 \%)$ risk of $\mathrm{HBV}$ reactivation in response to immunosuppressive or anticancer chemotherapy is well described in the KASL guidelines. ${ }^{9}$ Currently, most guidelines, including the KASL, AASLD, ESAL, and APASL, recommend the initiation of NAs (entecavir or tenofovir DF/AF) before immunosuppression or chemotherapy in HBsAg-positive or HBV DNA-detected patients (Table 8). ${ }^{6-9}$ Not all patients who are exclusively anti-HBc-positive (HBsAg-negative and HBV DNA-undetectable) require routine administration of NAs before immunosuppression or chemotherapy. However, NA therapy should be initiated promptly if there is a high risk of reactivation (e.g., treated with a rituximab-containing regimen) or detectable HBV DNA and/or reversion of HBsAg during follow-ups. NAs should be continued during and at least 6 months (or 12 months for rituximab therapy) after the cessation of immunosuppressive therapy or chemotherapy. ${ }^{6-9}$

\section{Pregnant women}

Immunological changes occur during pregnancy, and HBV may replicate more actively. ${ }^{88}$ Immune responses are restored at the late phase of pregnancy or after delivery, leading to ALT flares. Hence, NA therapy may need to be initiated in patients during or after pregnancy. ${ }^{89,90}$ Moreover, a high level of HBV DNA is related to an increased risk of mother-to-child viral transmission despite vaccine administration and hepatitis B immune globulin prophylaxis. ${ }^{88}$ Currently, the NAs evaluated for safety and efficacy during pregnancy include lamivudine, ${ }^{91}$ telbivudine, ${ }^{92}$ and tenofovir DF. ${ }^{93-95}$ Among these, tenofovir DF is the preferred NA owing to its excellent potency and high genetic barrier to resistance. Most guidelines recommend using tenofovir DF over other NAs for CHB treatment during pregnancy (Table 8). Additionally, the prophylactic use of tenofovir DF is recommended to prevent mother-to-child transmission beginning at 24-32 weeks of pregnancy (24-28 weeks by the EASL, 28-32 weeks by the AASLD and APASL, and 24-32 weeks by the KASL) and continuing until 2-12 weeks after delivery if pregnant women show serum HBV DNA levels $>200,000 \mathrm{IU} / \mathrm{mL}^{6-9}$

The KASL, AASLD, and EASL agree that breastfeeding is generally not contraindicated, even if tenofovir DF is being administered to the mother, based on previous studies. ${ }^{6,7,9,96}$ However, the
AASLD is somewhat cautious about this issue, suggesting there are insufficient long-term safety data. ${ }^{6}$ The APASL discourages breastfeeding during maternal NA treatment, which may need to be updated. ${ }^{8}$

\section{Acute hepatitis B}

Although acute hepatitis B is generally a self-limiting disease, severe cases resulting in hepatic failure, liver transplantation, or even death have been reported, albeit uncommonly. ${ }^{97}$ The use of antivirals in severely ill patients has been debated. While NA therapy might delay HBsAg sero-clearance, NA therapy can significantly reduce the mortality rate in patients with severe acute hepatitis $B{ }^{98}$ Considering this, the KASL guidelines recommend initiating NA therapy in patients with severe acute hepatitis $B$ (e.g., coagulopathy, severe jaundice, or liver failure) in agreement with other guidelines. ${ }^{9}$

The AASLD recommends using entecavir or tenofovir DF/AF, whereas the EASL refrains from recommending tenofovir AF owing to a lack of data. ${ }^{6,7}$ The APASL includes lamivudine, telbivudine, or adefovir for severe acute hepatitis B considering their relatively short therapy duration. ${ }^{8}$ They also recommend initiating NA treatment when it is difficult to distinguish between true severe acute hepatitis $B$ and spontaneous reactivation of chronic HBV infection. ${ }^{8}$

\section{CONCLUSIONS}

The KASL clinical practice guidelines for the management of CHB were recently revised, given the emergence of new NAs and continuously updated data regarding treatment initiation, modification, and cessation. Considering the 4- to 5-year interval of guideline revisions, other international guidelines are expected to be updated soon. Through a thorough and systematic approach for the management of CHB based on clinical practice guidelines, the cure of chronic HBV infection is expected to be a real treatment endpoint in the near future.

\section{Authors' contribution}

YHJ conceptualized and designed the study. YHJ, KJH, PJY, YEL, $\mathrm{PH}, \mathrm{KJH}, \mathrm{SDH}, \mathrm{LSH}, \mathrm{LJ}-\mathrm{H}$, and LHW performed a review of literature, revised the current KASL guidelines, and incorporated those revisions into the manuscript through interactive discussion. $\mathrm{YHJ}$ wrote the manuscript. YHJ, KJH, PJY, YEL, PH, KJH, SDH, LSH, LJ- 
$H$, and LHW reviewed and approved the final submission of the manuscript.

\section{Acknowledgements}

This work was funded in part by the Korean Association for the Study of the Liver and Korea University Research Grants.

\section{Conflicts of Interest}

YHJ received research funds from Gilead Sciences Korea, Ildong Pharm, and Yuhan Corporation. LJ-H received honoraria from Gilead Science Korea, and Daewoong Pharm during the conduct of the study. KJH, PJY, YEL, PH, KJH, SDH, LSH, and LHW have nothing to disclose.

\section{REFERENCES}

1. Schweitzer A, Horn J, Mikolajczyk RT, Krause G, Ott JJ. Estimations of worldwide prevalence of chronic hepatitis $B$ virus infection: a systematic review of data published between 1965 and 2013. Lancet 2015;386:1546-1555.

2. Chae HB, Kim JH, Kim JK, Yim HJ. Current status of liver diseases in Korea: hepatitis B. Korean J Hepatol 2009;15 Suppl 6:S13-S24.

3. Yim HJ, Lok AS. Natural history of chronic hepatitis B virus infection: what we knew in 1981 and what we know in 2005. Hepatology 2006;43(2 Suppl 1):S173-S181.

4. Liang $L Y$, Wong GL. Unmet need in chronic hepatitis B management. Clin Mol Hepatol 2019;25:172-180.

5. Tang LSY, Covert E, Wilson E, Kottilil S. Chronic hepatitis B infection: a review. JAMA 2018;319:1802-1813.

6. Terrault NA, Lok ASF, McMahon BJ, Chang KM, Hwang JP, Jonas $M M$, et al. Update on prevention, diagnosis, and treatment of chronic hepatitis B: AASLD 2018 hepatitis B guidance. Hepatology 2018;67:1560-1599.

7. European Association for the Study of the Liver. EASL 2017 clinical practice guidelines on the management of hepatitis $B$ virus infection. J Hepatol 2017;67:370-398.

8. Sarin SK, Kumar M, Lau GK, Abbas Z, Chan HL, Chen CJ, et al. Asian-Pacific clinical practice guidelines on the management of hepatitis B: a 2015 update. Hepatol Int 2016;10:1-98.

9. Korean Association for the Study of the Liver (KASL). KASL clinical practice guidelines for management of chronic hepatitis B. Clin Mol Hepatol 2019;25:93-159.

10. Park HN, Sinn DH, Gwak GY, Kim JE, Rhee SY, Eo SJ, et al. Upper normal threshold of serum alanine aminotransferase in identifying individuals at risk for chronic liver disease. Liver Int 2012;32:937944.
11. Park JY, Park YN, Kim DY, Paik YH, Lee KS, Moon BS, et al. High prevalence of significant histology in asymptomatic chronic hepatitis $B$ patients with genotype $C$ and high serum HBV DNA levels. J Viral Hepat 2008;15:615-621.

12. Shim JJ, Kim JW, Oh CH, Lee YR, Lee JS, Park SY, et al. Serum alanine aminotransferase level and liver-related mortality in patients with chronic hepatitis B: a large national cohort study. Liver Int 2018:38:1751-1759.

13. Kim GA, Lim YS, Han S, Choi J, Shim JH, Kim KM, et al. High risk of hepatocellular carcinoma and death in patients with immunetolerant-phase chronic hepatitis B. Gut 2018;67:945-952.

14. Wong GL. Management of chronic hepatitis B patients in immunetolerant phase: what latest guidelines recommend. Clin Mol Hepatol 2018;24:108-113.

15. Livingston SE, Simonetti JP, Bulkow LR, Homan CE, Snowball MM, Cagle $\mathrm{HH}$, et al. Clearance of hepatitis $B$ e antigen in patients with chronic hepatitis B and genotypes A, B, C, D, and F. Gastroenterology 2007;133:1452-1457.

16. Hsu YS, Chien RN, Yeh CT, Sheen IS, Chiou HY, Chu CM, et al. Longterm outcome after spontaneous HBeAg seroconversion in patients with chronic hepatitis B. Hepatology 2002;35:1522-1527.

17. Korean Association for the Study of the Liver. KASL clinical practice guidelines: management of chronic hepatitis B. Clin Mol Hepatol 2016;22:18-75.

18. Funk ML, Rosenberg DM, Lok AS. World-wide epidemiology of HBeAg-negative chronic hepatitis B and associated precore and core promoter variants. J Viral Hepat 2002;9:52-61.

19. Lok AS, Akarca U, Greene $S$. Mutations in the pre-core region of hepatitis $B$ virus serve to enhance the stability of the secondary structure of the pre-genome encapsidation signal. Proc Natl Acad Sci U S A 1994;91:4077-4081.

20. Croagh CM, Bell SJ, Slavin J, Kong YX, Chen RY, Locarnini S, et al. Increasing hepatitis $B$ viral load is associated with risk of significant liver fibrosis in $\mathrm{HBeAg}$-negative but not $\mathrm{HBeAg}$-positive chronic hepatitis B. Liver Int 2010;30:1115-1122.

21. Chen YC, Sheen IS, Chu CM, Liaw YF. Prognosis following spontaneous HBsAg seroclearance in chronic hepatitis B patients with or without concurrent infection. Gastroenterology 2002;123:10841089.

22. Kim GA, Lim YS, An J, Lee D, Shim JH, Kim KM, et al. HBsAg seroclearance after nucleoside analogue therapy in patients with chronic hepatitis B: clinical outcomes and durability. Gut 2014;63:13251332.

23. Iloeje UH, Yang HI, Su J, Jen CL, You SL, Chen CJ, et al. Predicting cirrhosis risk based on the level of circulating hepatitis B viral load. Gastroenterology 2006;130:678-686.

24. Chen CJ, Yang HI, Su J, Jen CL, You SL, Lu SN, et al. Risk of hepatocellular carcinoma across a biological gradient of serum hepatitis $B$ 
Hyung Joon Yim, et al.

Comparison of $\mathrm{CHB}$ guidelines

virus DNA level. JAMA 2006;295:65-73.

25. Liaw YF, Sung JJ, Chow WC, Farrell G, Lee CZ, Yuen H, et al. Lamivudine for patients with chronic hepatitis $B$ and advanced liver disease. N Engl J Med 2004;351:1521-1531.

26. Chang TT, Liaw YF, Wu SS, Schiff E, Han KH, Lai CL, et al. Long-term entecavir therapy results in the reversal of fibrosis/cirrhosis and continued histological improvement in patients with chronic hepatitis B. Hepatology 2010;52:886-893.

27. Cho H, Ahn H, Lee DH, Lee JH, Jung YJ, Chang Y, et al. Entecavir and tenofovir reduce hepatitis $B$ virus-related hepatocellular carcinoma recurrence more effectively than other antivirals. J Viral Hepat 2018;25:707-717.

28. Kim WR, Loomba R, Berg T, Aguilar Schall RE, Yee LJ, Dinh PV, et al. Impact of long-term tenofovir disoproxil fumarate on incidence of hepatocellular carcinoma in patients with chronic hepatitis B. Cancer 2015;121:3631-3638.

29. Marcellin P, Gane E, Buti M, Afdhal N, Sievert W, Jacobson IM, et al. Regression of cirrhosis during treatment with tenofovir disoproxil fumarate for chronic hepatitis B: a 5-year open-label follow-up study. Lancet 2013;381:468-475.

30. Kim MN, Kim SU, Kim BK, Park JY, Kim DY, Ahn SH, et al. Increased risk of hepatocellular carcinoma in chronic hepatitis B patients with transient elastography-defined subclinical cirrhosis. Hepatology 2015;61:1851-1859.

31. Lok AS, McMahon BJ. Chronic hepatitis B: update 2009. Hepatology 2009;50:661-662.

32. Chang Y, Choe WH, Sinn DH, Lee JH, Ahn SH, Lee H, et al. Nucleos(t) ide analogue treatment for patients with hepatitis B virus (HBV) e antigen-positive chronic HBV genotype C infection: a nationwide, multicenter, retrospective study. J Infect Dis 2017;216:1407-1414.

33. Song BC, Cho YK, Jwa H, Choi EK, Kim HU, Song HJ, et al. Is it necessary to delay antiviral therapy for 3-6 months to anticipate $\mathrm{HBeAg}$ seroconversion in patients with $\mathrm{HBeAg}$-positive chronic hepatitis B in endemic areas of HBV genotype C? Clin Mol Hepatol 2014;20:355-360.

34. Wong VW, Wong GL, Yiu KK, Chim AM, Chu SH, Chan HY, et al. Entecavir treatment in patients with severe acute exacerbation of chronic hepatitis B. J Hepatol 2011;54:236-242.

35. Cao Z, Liu Y, Ma L, Lu J, Jin Y, Ren S, et al. A potent hepatitis B surface antigen response in subjects with inactive hepatitis $B$ surface antigen carrier treated with pegylated-interferon alpha. Hepatology 2017;66:1058-1066.

36. Sinn DH, Lee J, Goo J, Kim K, Gwak GY, Paik YH, et al. Hepatocellular carcinoma risk in chronic hepatitis B virus-infected compensated cirrhosis patients with low viral load. Hepatology 2015;62:694-701.

37. Li WC, Wang MR, Kong LB, Ren WG, Zhang YG, Nan YM. Peginterferon alpha-based therapy for chronic hepatitis B focusing on $\mathrm{HBsAg}$ clearance or seroconversion: a meta-analysis of controlled clinical trials. BMC Infect Dis 2011;11:165.

38. Cooksley WG, Piratvisuth T, Lee SD, Mahachai V, Chao YC, Tanwandee $T$, et al. Peginterferon alpha-2a (40 kDa): an advance in the treatment of hepatitis B e antigen-positive chronic hepatitis B. J Viral Hepat 2003;10:298-305.

39. Moucari R, Mackiewicz V, Lada O, Ripault MP, Castelnau C, Martinot-Peignoux $\mathrm{M}$, et al. Early serum HBsAg drop: a strong predictor of sustained virological response to pegylated interferon alfa-2a in HBeAg-negative patients. Hepatology 2009;49:1151-1157.

40. Chang TT, Lai CL, Kew Yoon S, Lee SS, Coelho HS, Carrilho FJ, et al. Entecavir treatment for up to 5 years in patients with hepatitis $B$ e antigen-positive chronic hepatitis B. Hepatology 2010;51:422-430.

41. Liu Y, Corsa AC, Buti M, Cathcart AL, Flaherty JF, Miller MD, et al. No detectable resistance to tenofovir disoproxil fumarate in $\mathrm{HBeAg}+$ and $\mathrm{HBeAg}$ - patients with chronic hepatitis B after 8 years of treatment. J Viral Hepat 2017;24:68-74.

42. Yim HJ, Hwang SG. Options for the management of antiviral resistance during hepatitis B therapy: reflections on battles over a decade. Clin Mol Hepatol 2013;19:195-209.

43. Ahn SH, Kim W, Jung YK, Yang JM, Jang JY, Kweon YO, et al. Efficacy and safety of besifovir dipivoxil maleate compared with tenofovir disoproxil fumarate in treatment of chronic hepatitis B virus infection. Clin Gastroenterol Hepatol 2019;17:1850-1859.e4.

44. Agarwal K, Brunetto M, Seto WK, Lim YS, Fung S, Marcellin P, et al. 96 weeks treatment of tenofovir alafenamide vs. tenofovir disoproxil fumarate for hepatitis B virus infection. J Hepatol 2018;68:672-681.

45. Buti M, Gane E, Seto WK, Chan HL, Chuang WL, Stepanova T, et al. Tenofovir alafenamide versus tenofovir disoproxil fumarate for the treatment of patients with $\mathrm{HBeAg-negative} \mathrm{chronic} \mathrm{hepatitis} \mathrm{B} \mathrm{virus}$ infection: a randomised, double-blind, phase 3, non-inferiority trial. Lancet Gastroenterol Hepatol 2016;1:196-206.

46. Yoon EL, Yim HJ, Lee HJ, Lee YS, Kim JH, Jung ES, et al. Comparison of clevudine and entecavir for treatment-naive patients with chronic hepatitis B virus infection: two-year follow-up data. J Clin Gastroenterol 2011;45:893-899.

47. Su QM, Ye XG. Effects of telbivudine and entecavir for HBeAgpositive chronic hepatitis B: a meta-analysis. World J Gastroenterol 2012;18:6290-6301.

48. Tak WY, Park SY, Cho CM, Jung MK, Jeon SW, Kweon YO, et al. Clinical, biochemical, and pathological characteristics of clevudineassociated myopathy. J Hepatol 2010;53:261-266.

49. Kim EH, Park H, Lee KH, Ahn SH, Kim SM, Han KH. Two cases of telbivudine-induced myopathy in siblings with chronic hepatitis $B$. Clin Mol Hepatol 2013;19:82-86.

50. Choi J, Kim HJ, Lee J, Cho S, Ko MJ, Lim YS. Risk of hepatocellular carcinoma in patients treated with entecavir vs tenofovir for chronic hepatitis B: a Korean nationwide cohort study. JAMA Oncol 2019;5:30-36. 
51. Kim SU, Seo YS, Lee HA, Kim MN, Lee YR, Lee HW, et al. A multicenter study of entecavir vs. tenofovir on prognosis of treatmentnaïve chronic hepatitis B in South Korea. J Hepatol 2019;71:456464.

52. Lee SW, Kwon JH, Lee HL, Yoo SH, Nam HC, Sung PS, et al. Comparison of tenofovir and entecavir on the risk of hepatocellular carcinoma and mortality in treatment-naïve patients with chronic hepatitis B in Korea: a large-scale, propensity score analysis. Gut 2020;69:1301-1308.

53. Yip TC, Wong VW, Chan HL, Tse YK, Lui GC, Wong GL. Tenofovir is associated with lower risk of hepatocellular carcinoma than entecavir in patients with chronic HBV infection in China. Gastroenterology 2020;158:215-225.e6.

54. Toy M, Hutton DW, So SK. Cost-effectiveness and cost thresholds of generic and brand drugs in a national chronic hepatitis B treatment program in China. PLoS One 2015;10:e0139876.

55. Kim DY, Kim JH, Tak WY, Yeon JE, Lee JH, Yoon JH, et al. Baracle ${ }^{\circledR}$ vs Baraclude $\AA$ for 48 weeks in patients with treatment-naïve chronic hepatitis B: a comparison of efficacy and safety. Drug Des Devel Ther 2017;11:3145-3152.

56. Kim JH, Sinn DH, Kang W, Gwak GY, Paik YH, Choi MS, et al. Lowlevel viremia and the increased risk of hepatocellular carcinoma in patients receiving entecavir treatment. Hepatology 2017;66:335343.

57. Yim HJ, Kim IH, Suh SJ, Jung YK, Kim JH, Seo YS, et al. Switching to tenofovir vs continuing entecavir for hepatitis $B$ virus with partial virologic response to entecavir: a randomized controlled trial. J Viral Hepat 2018;25:1321-1330.

58. Park ES, Lee AR, Kim DH, Lee JH, Yoo JJ, Ahn SH, et al. Identification of a quadruple mutation that confers tenofovir resistance in chronic hepatitis B patients. J Hepatol 2019;70:1093-1102.

59. Sheldon J, Camino N, Rodés B, Bartholomeusz A, Kuiper M, Tacke $F$, et al. Selection of hepatitis $B$ virus polymerase mutations in HIVcoinfected patients treated with tenofovir. Antivir Ther 2005;10:727734.

60. Yeon JE, Yoo W, Hong SP, Chang YJ, Yu SK, Kim JH, et al. Resistance to adefovir dipivoxil in lamivudine resistant chronic hepatitis B patients treated with adefovir dipivoxil. Gut 2006;55:1488-1495.

61. Yim HJ, Hussain M, Liu Y, Wong SN, Fung SK, Lok AS. Evolution of multi-drug resistant hepatitis $B$ virus during sequential therapy. Hepatology 2006;44:703-712.

62. Lee S, Ahn SH, Jung KS, Kim DY, Kim BK, Kim SU, et al. Tenofovir versus tenofovir plus entecavir for chronic hepatitis B with lamivudine resistance and entecavir resistance. J Viral Hepat 2017;24:141147.

63. Lee HW, Park JY, Lee JW, Yoon KT, Kim CW, Park H, et al. Longterm efficacy of tenofovir disoproxil fumarate monotherapy for multidrug-resistant chronic HBV infection. Clin Gastroenterol Hepa- tol 2019;17:1348-1355.e2.

64. Lee JW, Lee YJ, Lee JJ, Kim JH, Jung YK, Kwon OS, et al. Efficacy of entecavir switching therapy in chronic hepatitis $B$ patients with clevudine-induced myopathy. Korean J Gastroenterol 2013;61:3036.

65. Duarte-Rojo A, Heathcote EJ. Efficacy and safety of tenofovir disoproxil fumarate in patients with chronic hepatitis B. Therap Adv Gastroenterol 2010;3:107-119.

66. Lau GK, Piratvisuth T, Luo KX, Marcellin P, Thongsawat S, Cooksley $G$, et al. Peginterferon alfa-2a, lamivudine, and the combination for HBeAg-positive chronic hepatitis B. N Engl J Med 2005;352:26822695.

67. Chen X, Chen X, Chen W, Ma X, Huang J, Chen R. Extended peginterferon alfa-2a (Pegasys) therapy in Chinese patients with HBeAgnegative chronic hepatitis B. J Med Virol 2014;86:1705-1713.

68. Lampertico P, Viganò M, Di Costanzo GG, Sagnelli E, Fasano M, Di Marco $V$, et al. Randomised study comparing 48 and 96 weeks peginterferon a-2a therapy in genotype $D$ HBeAg-negative chronic hepatitis B. Gut 2013;62:290-298.

69. Lee HW, Lee HJ, Hwang JS, Sohn JH, Jang JY, Han KJ, et al. Lamivudine maintenance beyond one year after $\mathrm{HBeAg}$ seroconversion is a major factor for sustained virologic response in $\mathrm{HBeAg}$-positive chronic hepatitis B. Hepatology 2010;51:415-421.

70. Kim YJ, Kim K, Hwang SH, Kim SS, Lee D, Cheong JY, et al. Durability after discontinuation of nucleos(t)ide therapy in chronic $\mathrm{HBeAg}$ negative hepatitis patients. Clin Mol Hepatol 2013;19:300-304.

71. Kang SH, Kang K, Jong Eun Y, Lee YS, Kim TS, Yoo YJ, et al. Antiviral response is not sustained after cessation of lamivudine treatment in chronic hepatitis B patients: a 10-year follow-up study. J Med Virol 2017:89:849-856.

72. Chen CH, Lu SN, Hung CH, Wang JH, Hu TH, Changchien CS, et al. The role of hepatitis $B$ surface antigen quantification in predicting HBsAg loss and HBV relapse after discontinuation of lamivudine treatment. J Hepatol 2014;61:515-522.

73. Lee HA, Seo YS, Park SW, Park SJ, Kim TH, Suh SJ, et al. Hepatitis B surface antigen titer is a good indicator of durable viral response after entecavir off-treatment for chronic hepatitis B. Clin Mol Hepatol 2016;22:382-389.

74. Terrault NA, Bzowej NH, Chang KM, Hwang JP, Jonas MM, Murad MH. AASLD guidelines for treatment of chronic hepatitis B. Hepatology 2016;63:261-283.

75. Wu CY, Chen YJ, Ho HJ, Hsu YC, Kuo KN, Wu MS, et al. Association between nucleoside analogues and risk of hepatitis B virus-related hepatocellular carcinoma recurrence following liver resection. JAMA 2012;308:1906-1914.

76. Yin J, Li N, Han Y, Xue J, Deng Y, Shi J, et al. Effect of antiviral treatment with nucleotide/nucleoside analogs on postoperative prognosis of hepatitis B virus-related hepatocellular carcinoma: a two- 
Hyung Joon Yim, et al.

Comparison of $\mathrm{CHB}$ guidelines

stage longitudinal clinical study. J Clin Oncol 2013;31:3647-3655.

77. Kumada T, Toyoda H, Tada T, Kiriyama S, Tanikawa M, Hisanaga Y, et al. Effect of nucleos(t)ide analogue therapy on hepatocarcinogenesis in chronic hepatitis B patients: a propensity score analysis. J Hepatol 2013;58:427-433.

78. Jang JW, Choi JY, Bae SH, Yoon SK, Chang UI, Kim CW, et al. A randomized controlled study of preemptive lamivudine in patients receiving transarterial chemo-lipiodolization. Hepatology 2006;43:233-240.

79. Nagamatsu H, Itano S, Nagaoka S, Akiyoshi J, Matsugaki S, Kurogi J, et al. Prophylactic lamivudine administration prevents exacerbation of liver damage in $\mathrm{HBe}$ antigen positive patients with hepatocellular carcinoma undergoing transhepatic arterial infusion chemotherapy. Am J Gastroenterol 2004;99:2369-2375.

80. Chen G, Lin W, Shen F, Iloeje UH, London WT, Evans AA. Chronic hepatitis $B$ virus infection and mortality from non-liver causes: results from the Haimen City cohort study. Int J Epidemiol 2005;34:132-137.

81. Marcucci F, Spada E, Mele A, Caserta CA, Pulsoni A. The association of hepatitis B virus infection with B-cell non-Hodgkin lymphoma - a review. Am J Blood Res 2012;2:18-28.

82. Hsu C, Tsou HH, Lin SJ, Wang MC, Yao M, Hwang WL, et al. Chemotherapy-induced hepatitis $B$ reactivation in lymphoma patients with resolved HBV infection: a prospective study. Hepatology 2014:59:2092-2100

83. Liu WP, Wang XP, Zheng W, Ping LY, Zhang $C$, Wang GQ, et al. Hepatitis $B$ virus reactivation after withdrawal of prophylactic antiviral therapy in patients with diffuse large B cell lymphoma. Leuk Lymphoma 2016;57:1355-1362.

84. Dong HJ, Ni LN, Sheng GF, Song HL, Xu JZ, Ling Y. Risk of hepatitis $B$ virus (HBV) reactivation in non-Hodgkin lymphoma patients receiving rituximab-chemotherapy: a meta-analysis. J Clin Virol 2013:57:209-214.

85. Lau GK, Yiu HH, Fong DY, Cheng HC, Au WY, Lai LS, et al. Early is superior to deferred preemptive lamivudine therapy for hepatitis B patients undergoing chemotherapy. Gastroenterology 2003;125:1742-1749.

86. Huang YH, Hsiao LT, Hong YC, Chiou TJ, Yu YB, Gau JP, et al. Randomized controlled trial of entecavir prophylaxis for rituximabassociated hepatitis B virus reactivation in patients with lymphoma and resolved hepatitis B. J Clin Oncol 2013;31:2765-2772.

87. Loomba R, Liang TJ. Hepatitis B reactivation associated with immune suppressive and biological modifier therapies: current concepts, management strategies, and future directions. Gastroenterology
2017;152:1297-1309.

88. Söderström A, Norkrans $G$, Lindh $M$. Hepatitis B virus DNA during pregnancy and post partum: aspects on vertical transmission. Scand $J$ Infect Dis 2003:35:814-819.

89. ter Borg MJ, Leemans WF, de Man RA, Janssen HL. Exacerbation of chronic hepatitis B infection after delivery. J Viral Hepat 2008;15:3741.

90. Chang CY, Aziz N, Poongkunran M, Javaid A, Trinh HN, Lau D, et al. Serum alanine aminotransferase and hepatitis B DNA flares in pregnant and postpartum women with chronic hepatitis B. Am J Gastroenterol 2016;111:1410-1415.

91. van Zonneveld $M$, van Nunen $A B$, Niesters $H G$, de Man RA, Schalm SW, Janssen $\mathrm{HL}$. Lamivudine treatment during pregnancy to prevent perinatal transmission of hepatitis B virus infection. J Viral Hepat 2003;10:294-297.

92. Han GR, Cao MK, Zhao W, Jiang HX, Wang CM, Bai SF, et al. A prospective and open-label study for the efficacy and safety of telbivudine in pregnancy for the prevention of perinatal transmission of hepatitis B virus infection. J Hepatol 2011;55:1215-1221.

93. Chen HL, Lee CN, Chang CH, Ni YH, Shyu MK, Chen SM, et al. Efficacy of maternal tenofovir disoproxil fumarate in interrupting mother-toinfant transmission of hepatitis B virus. Hepatology 2015;62:375386.

94. Pan CQ, Duan Z, Dai E, Zhang S, Han G, Wang Y, et al. Tenofovir to prevent hepatitis $B$ transmission in mothers with high viral load. $N$ Engl J Med 2016;374:2324-2334.

95. Hyun MH, Lee YS, Kim JH, Je JH, Yoo YJ, Yeon JE, et al. Systematic review with meta-analysis: the efficacy and safety of tenofovir to prevent mother-to-child transmission of hepatitis B virus. Aliment Pharmacol Ther 2017;45:1493-1505.

96. Benaboud S, Pruvost A, Coffie PA, Ekouévi DK, Urien S, Arrivé E, et al. Concentrations of tenofovir and emtricitabine in breast milk of HIV-1-infected women in Abidjan, Cote d'Ivoire, in the ANRS 12109 TEmAA study, step 2. Antimicrob Agents Chemother 2011;55:13151317.

97. Wang CY, Zhao P, Liu WW; Acute Liver Failure Study Team. Acute liver failure caused by severe acute hepatitis B: a case series from a multi-center investigation. Ann Clin Microbiol Antimicrob 2014;13:23.

98. Miyake Y, Iwasaki Y, Takaki A, Fujioka S, Takaguchi K, Ikeda H, et al. Lamivudine treatment improves the prognosis of fulminant hepatitis B. Intern Med 2008;47:1293-1299. 